Cochrane Database of Systematic Reviews

\title{
Interventions for haemolytic uraemic syndrome and thrombotic thrombocytopenic purpura (Review)
}

Michael M, Elliott EJ, Ridley GF, Hodson EM, Craig JC

Michael M, Elliott EJ, Ridley GF, Hodson EM, Craig JC.

Interventions for haemolytic uraemic syndrome and thrombotic thrombocytopenic purpura.

Cochrane Database of Systematic Reviews 2009, Issue 1. Art. No.: CD003595.

DOI: 10.1002/14651858.CD003595.pub2.

www.cochranelibrary.com 
TABLE OF CONTENTS

HEADER

ABSTRACT

PLAIN LANGUAGE SUMMARY

BACKGROUND

OBJECTIVES

METHODS

RESULTS

Figure 1.

DISCUSSION

AUTHORS' CONCLUSIONS

\section{ACKNOWLEDGEMENTS}

REFERENCES

\section{CHARACTERISTICS OF STUDIES}

DATA AND ANALYSES

Analysis 1.1. Comparison 1 TTP studies: Any intervention versus plasma exchange (PE) with fresh-frozen plasma (FFP), Outcome 1 Failure of remission at 2 weeks.

Analysis 1.2. Comparison 1 TTP studies: Any intervention versus plasma exchange (PE) with fresh-frozen plasma (FFP), Outcome 2 Failure of remission at 1 month.

Analysis 1.3. Comparison 1 TTP studies: Any intervention versus plasma exchange (PE) with fresh-frozen plasma (FFP), Outcome 3 All-cause mortality.

Analysis 1.4. Comparison 1 TTP studies: Any intervention versus plasma exchange (PE) with fresh-frozen plasma (FFP), Outcome 4 Relapse rate.

Analysis 2.1. Comparison 2 TTP studies: Plasma exchange (PE) with cryosupernatant plasma (CSP) or cryoprecipitate poor plasma (CPP) versus plasma exchange with fresh-frozen plasma (FFP), Outcome 1 Failure of remission $<2$ weeks.

Analysis 2.2. Comparison 2 TTP studies: Plasma exchange (PE) with cryosupernatant plasma (CSP) or cryoprecipitate poor plasma (CPP) versus plasma exchange with fresh-frozen plasma (FFP), Outcome 2 Failure of remission at 1 month.

Analysis 2.3. Comparison 2 TTP studies: Plasma exchange (PE) with cryosupernatant plasma (CSP) or cryoprecipitate poor plasma (CPP) versus plasma exchange with fresh-frozen plasma (FFP), Outcome 3 All-cause mortality.

Analysis 2.4. Comparison 2 TTP studies: Plasma exchange (PE) with cryosupernatant plasma (CSP) or cryoprecipitate poor plasma (CPP) versus plasma exchange with fresh-frozen plasma (FFP), Outcome 4 Relapse rate.

Analysis 3.1. Comparison 3 TTP studies: Plasma infusions (PI) plus antiplatelet therapy (APT) versus plasma exchange (PE) with fresh-frozen plasma (FFP) plus APT, Outcome 1 Failure of remission $<2$ weeks.

Analysis 3.2. Comparison 3 TTP studies: Plasma infusions (PI) plus antiplatelet therapy (APT) versus plasma exchange (PE) with fresh-frozen plasma (FFP) plus APT, Outcome 2 Failure to respond (remission) at $>2$ weeks to 6 months.

Analysis 3.3. Comparison 3 TTP studies: Plasma infusions (PI) plus antiplatelet therapy (APT) versus plasma exchange (PE) with fresh-frozen plasma (FFP) plus APT, Outcome 3 All-cause mortality.

Analysis 3.4. Comparison 3 TTP studies: Plasma infusions (PI) plus antiplatelet therapy (APT) versus plasma exchange (PE) with fresh-frozen plasma (FFP) plus APT, Outcome 4 Relapse rate.

Analysis 4.1. Comparison 4 TTP studies: Antiplatelet therapy (APT) plus plasma exchange (PE) with fresh-frozen plasma (FFP) and steroids versus PE with FFP and steroids, Outcome 1 Failure of remission at 2 weeks.

Analysis 4.2. Comparison 4 TTP studies: Antiplatelet therapy (APT) plus plasma exchange (PE) with fresh-frozen plasma (FFP) and steroids versus PE with FFP and steroids, Outcome 2 Failure of remission $>2$ weeks.

Analysis 4.3. Comparison 4 TTP studies: Antiplatelet therapy (APT) plus plasma exchange (PE) with fresh-frozen plasma (FFP) and steroids versus PE with FFP and steroids, Outcome 3 All-cause mortality.

Analysis 4.4. Comparison 4 TTP studies: Antiplatelet therapy (APT) plus plasma exchange (PE) with fresh-frozen plasma (FFP) and steroids versus PE with FFP and steroids, Outcome 4 Relapse rate.

Analysis 5.1. Comparison 5 HUS studies: Any intervention plus supportive therapy versus supportive therapy alone, Outcome 1 All-cause mortality.

Analysis 5.2. Comparison 5 HUS studies: Any intervention plus supportive therapy versus supportive therapy alone, Outcome 2 Neurological and extra renal events.

Analysis 5.3. Comparison 5 HUS studies: Any intervention plus supportive therapy versus supportive therapy alone, Outcome 3 Proteinuria at last follow-up.

Analysis 5.4. Comparison 5 HUS studies: Any intervention plus supportive therapy versus supportive therapy alone, Outcome 4 Hypertension at last follow-up. 
Analysis 6.1. Comparison 6 HUS studies: Anticoagulation (heparin +/- dipyridamole or urokinase) plus supportive therapy versus supportive therapy alone, Outcome 1 All-cause mortality.

Analysis 6.2. Comparison 6 HUS studies: Anticoagulation (heparin +/- dipyridamole or urokinase) plus supportive therapy versus supportive therapy alone, Outcome 2 Neurological events: Children with seizures.

Analysis 6.4. Comparison 6 HUS studies: Anticoagulation (heparin +/- dipyridamole or urokinase) plus supportive therapy versus supportive therapy alone, Outcome 4 Renal biopsy: Thrombotic microangiopathy.

Analysis 6.5. Comparison 6 HUS studies: Anticoagulation (heparin +/- dipyridamole or urokinase) plus supportive therapy versus supportive therapy alone, Outcome 5 Proteinuria $>0.10 \mathrm{~g} / 24 \mathrm{~h}$ at last follow-up.

Analysis 6.6. Comparison 6 HUS studies: Anticoagulation (heparin +/- dipyridamole or urokinase) plus supportive therapy versus supportive therapy alone, Outcome 6 Hypertension at last follow-up.

Analysis 6.8. Comparison 6 HUS studies: Anticoagulation (heparin +/- dipyridamole or urokinase) plus supportive therapy versus supportive therapy alone, Outcome 8 Adverse effect: Bleeding (RR).

Analysis 6.9. Comparison 6 HUS studies: Anticoagulation (heparin +/- dipyridamole or urokinase) plus supportive therapy versus supportive therapy alone, Outcome 9 Adverse effect: Bleeding (RD random effects model).

Analysis 6.10. Comparison 6 HUS studies: Anticoagulation (heparin +/- dipyridamole or urokinase) plus supportive therapy versus supportive therapy alone, Outcome 10 Adverse effect: Bleeding (RD fixed effect model).

Analysis 7.1. Comparison 7 HUS studies: Plasma infusion plus supportive therapy versus supportive therapy alone, Outcome 1 All-cause mortality.

Analysis 7.2. Comparison 7 HUS studies: Plasma infusion plus supportive therapy versus supportive therapy alone, Outcome 2 ESKD: Dialysis-dependent at 6 weeks.

Analysis 7.3. Comparison 7 HUS studies: Plasma infusion plus supportive therapy versus supportive therapy alone, Outcome 3 Proteinuria at last follow-up (12 months).

Analysis 7.4. Comparison 7 HUS studies: Plasma infusion plus supportive therapy versus supportive therapy alone, Outcome 4 Hypertension at last follow-up (12 months).

Analysis 8.1. Comparison 8 HUS studies: Methylprednisolone plus supportive therapy versus placebo plus supportive therapy, Outcome 1 All-cause mortality.

Analysis 8.2. Comparison 8 HUS studies: Methylprednisolone plus supportive therapy versus placebo plus supportive therapy, Outcome 2 Neurological events: Children with seizures.

Analysis 8.3. Comparison 8 HUS studies: Methylprednisolone plus supportive therapy versus placebo plus supportive therapy, Outcome 3 Adverse effects: Peritonitis.

Analysis 9.1. Comparison 9 HUS studies: Shiga toxin binding agent plus supportive therapy versus placebo plus supportive care, Outcome 1 All-cause mortality.

Analysis 9.2. Comparison 9 HUS studies: Shiga toxin binding agent plus supportive therapy versus placebo plus supportive care, Outcome 2 Extrarenal events.

Analysis 9.3. Comparison 9 HUS studies: Shiga toxin binding agent plus supportive therapy versus placebo plus supportive care, Outcome 3 Proteinuria $\geq 2$ at last follow-up (60 days).

Analysis 9.4. Comparison 9 HUS studies: Shiga toxin binding agent plus supportive therapy versus placebo plus supportive care, Outcome 4 Hypertension at last follow-up (60 days).

Analysis 9.5. Comparison 9 HUS studies: Shiga toxin binding agent plus supportive therapy versus placebo plus supportive care, Outcome $5 \mathrm{GFR}<90 \mathrm{~mL} / \mathrm{min} / 1.73 \mathrm{~m}^{2}$ at last follow-up (60 days).

APPENDICES

WHAT'S NEW

CONTRIBUTIONS OF AUTHORS

DECLARATIONS OF INTEREST

SOURCES OF SUPPORT

INDEX TERMS 
[Intervention Review]

\section{Interventions for haemolytic uraemic syndrome and thrombotic thrombocytopenic purpura}

Mini Michael ${ }^{1}$, Elizabeth J Elliott ${ }^{2}$, Greta F Ridley ${ }^{3}$, Elisabeth M Hodson ${ }^{4}$, Jonathan C Craig ${ }^{4}$

1 Renal Section, Department of Pediatrics, Texas Children's Hospital/Baylor College of Medicine, Houston, Texas, USA. 2Department of Paediatrics and Child Health, Director of Centre for Evidence Based Paediatric Gastroenterology and Nutrition (CEBPGAN), The Children's Hospital at Westmead; The University of Sydney, Westmead, Australia. ${ }^{3}$ Australian Paediatric Surveillance Unit, The Children's Hospital at Westmead, Westmead, Australia. ${ }^{4}$ Centre for Kidney Research, The Children's Hospital at Westmead, Westmead, Australia

Contact address: Mini Michael, Renal Section, Department of Pediatrics, Texas Children's Hospital/Baylor College of Medicine, 6621 Fannin St, MC 3-2482, Houston, Texas, 77030, USA. mmichael@bcm.tmc.edu, mxmichae@TexasChildrensHospital.org.

Editorial group: Cochrane Kidney and Transplant Group.

Publication status and date: New, published in Issue 1, 2010.

Citation: Michael M, Elliott EJ, Ridley GF, Hodson EM, Craig JC. Interventions for haemolytic uraemic syndrome and thrombotic thrombocytopenic purpura. Cochrane Database of Systematic Reviews 2009, Issue 1. Art. No.: CD003595. DOI: 10.1002/14651858.CD003595.pub2.

Copyright (c) 2010 The Cochrane Collaboration. Published by John Wiley \& Sons, Ltd.

\section{A B S T R A C T}

\section{Background}

Haemolytic uraemic syndrome (HUS) and thrombotic thrombocytopenic purpura (TTP) are related conditions with similar clinical features of variable severity. Survival of patients with HUS and TTP has improved greatly over the past two decades with improved supportive care for patients with HUS and by the use of plasma exchange (PE) with fresh frozen plasma (FFP) for patients with TTP. Separate pathogenesis of these two disorders has become more evident, but management overlaps.

\section{Objectives}

To evaluate the benefits and harms of different interventions for HUS and TTP separately, in patients of all ages.

\section{Search methods}

We searched MEDLINE, EMBASE, the Cochrane Central Register of Controlled Trials (CENTRAL), conference proceedings, reference lists of articles and text books and contact with investigators were used to identify relevant studies.

\section{Selection criteria}

Randomised controlled trials (RCTs) evaluating any interventions for HUS or TTP in patients of all ages.

\section{Data collection and analysis}

Three authors independently extracted data and evaluated study reporting quality using standard Cochrane criteria. Analysis was undertaken using a random effects model and results expressed as risk ratio (RR) and 95\% confidence intervals (CI).

\section{Main results}

For TTP, we found six RCTs (331 participants) evaluating PE with FFP as the control. Interventions tested included antiplatelet therapy (APT) plus PE with FFP, FFP transfusion and PE with cryosupernatant plasma (CSP). Two studies compared plasma infusion (PI) to PE with FFP and showed a significant increase in failure of remission at two weeks (RR 1.48, 95\% 1.12 to 1.96) and all-cause mortality (RR 1.91, 95\% 1.09 to 3.33) in the PI group. Seven RCTs were undertaken in children with HUS. None of the assessed interventions used (FFP transfusion, heparin with or without urokinase or dipyridamole, shiga toxin binding protein and steroids) were superior to supportive therapy alone, for 
all-cause mortality, neurological/extrarenal events, renal biopsy changes, proteinuria or hypertension at the last follow-up visit. Bleeding was significantly higher in those receiving anticoagulation therapy compared to supportive therapy alone ( $\mathrm{RR} 25.89,95 \% \mathrm{Cl} 3.67$ to 182.83 ).

\section{Authors' conclusions}

PE with FFP is still the most effective treatment available for TTP. For patients with HUS, supportive therapy including dialysis is still the most effective treatment. All studies in HUS have been conducted in the diarrhoeal form of the disease. There were no RCTs evaluating the effectiveness of any interventions on patients with atypical HUS who have a more chronic and relapsing course.

\section{PLAIN LANGUAGE SUMMARY}

\section{Interventions for haemolytic uraemic syndrome and thrombotic thrombocytopenic purpura}

This review also showed that in patients with typical or diarrhoea associated haemolytic uraemic syndrome, there are no interventions that are superior to supportive therapy which includes control of fluid and electrolyte imbalance, use of dialysis if required, control of hypertension and blood transfusion as required. 


\section{B A C K G R O U N D}

Haemolytic uraemic syndrome (HUS) and thrombotic thrombocytopenic purpura (TTP) are related conditions with similar clinical features of variable severity. The clinical and pathologic features of TTP and HUS often overlap (Kaplan 1995), leading some to recommend the term "TTP-HUS". Although TTP and HUS can affect many of the same organ systems, the frequency with which they do so differs markedly, and the detailed histopathologic features of the lesions of TTP and HUS are distinct (Hosler 2003). Recent studies demonstrate that these disorders can be differentiated by the high incidence of severe deficiency of the VWF cleaving protease ADAMTS13 (a disintegrin and metalloprotease with thrombospodin) in patients with clinically diagnosed TTP (Bianchi 2002; Furlan 1998; Tsai 1998), but not HUS

ADAMTS13 levels are normal in some cases of idiopathic TTP and in almost all cases of thrombotic microangiopathy (TMA) associated with stem cell or organ transplantation, cancer, infections, severe hypertension, and certain drugs. Therefore, mechanisms other than ADAMTS13 deficiency can cause TMA and various studies have implicated endothelial injury, platelet activation, and alterations in blood clotting as contributory factors. TTP occurs with an estimated annual incidence of 3.7 cases/million (Torok 1995) and is more common in females (female/male ratio of 3:2) with a peak incidence occurring in the fourth decade (Vesely 2003). The mortality rate of TTP exceeds $90 \%$ without therapy. With the advent of plasma-based therapy there has been a dramatic improvement in the long-term survival, which now approaches $80 \%$ (Allford 2003). Two different forms of plasma therapy used, include plasma infusion (PI) (Byrnes 1977) and plasma exchange (PE) with fresh frozen plasma (FFP) (Bukowski 1976). Cryosupernatant PE (Rock 1996) and solvent/detergent-treated PE (SDTP) have also been used in the treatment of some patients with TTP (Sacher 1996). Over the last few decades several other interventions including steroids, other immunosuppressants such as vincristine, antiplatelet and thrombolytic agents have been studied in patients with TTP with varying results.

HUS usually affects young children and has been classified in several ways, the most common type, the "typical" form is associated with diarrhoea due to infection with a Shiga toxin producing Escherichia coli or Shigella dysenteriae. This form of HUS accounts for at least 95\% of all cases in children (Remuzzi 1995; Ruggenenti 2001) and may cause sporadic or epidemic disease. E. coli $0157: \mathrm{H} 7$ is the strain most commonly associated with HUS worldwide, however there is considerable geographic variation. Infection with Shiga toxin-producing organisms occasionally causes HUS in adults. The "atypical" forms of HUS, which may exhibit autosomal-dominant or recessive inheritance, are less common (Kaplan 1992). Some patients with a family history of HUS demonstrate persistently low levels of complement, caused by a homozygous deficiency of complement factor $\mathrm{H}$ (Taylor 2001). Their disease runs a chronic, relapsing course, often complicated by hypertension and renal insufficiency and exacerbations may be precipitated by intercurrent illness.

The overall incidence of HUS in children aged less than five years ranges from 1.1 to 5.8/100,000 (Bender 1997; Decludt 2000; Elliott 2001; Martin 1990; Milford 1990; Rowe 1991). Incidence has been estimated at $0.64 / 100,000$ children aged less than 15 years (Elliott 2001). The mortality rate ranges from $2.6 \%$ to $7.4 \%$ (Elliott
2001). Morbidity, in terms of end-stage kidney disease (ESKD) and mortality is higher (23\% and $22 \%$, respectively) in atypical HUS than in diarrhoea-associated disease (Neuhaus 1997). Unlike children, adults with HUS due to E. coli 0157:H7 infection have high mortality rates, up to $86 \%$ in the elderly (Decludt 2000).

The clinical course of HUS appears to depend on cause and age. Children with post-diarrhoeal HUS generally do well provided appropriate care is given in a timely fashion. The mortality rate in this group has been reduced to $5 \%$ with appropriate supportive care which include blood transfusion, correction of fluid and electrolyte imbalance, dialysis as required and control of hypertension (Banatvala 2001; Remuzzi 1995). Despite a favourable short-term outcome, many children with Shiga-toxin associated HUS develop chronic kidney disease (CKD) over time. Other forms of therapy which have been tried over the past two decades in patients with HUS, include steroids, antiplatelet and thrombolytic agents, vitamin $\mathrm{E}, \mathrm{PI}$ and $\mathrm{PE}$.

The mainstay of treatment for HUS and TTP is supportive therapy and there is no consensus on the role of specific therapies, many of which have been proposed for these diseases. In this review we aim to identify interventions evaluated by RCT in patients with HUS and TTP and evaluate their effectiveness in respect to our clinical outcomes of interest including failure of remission, death and other severe complications, relapse, ESKD and persistent renal impairment.

\section{O B JECT IVES}

The aim of this review was to evaluate the benefits and harms of different interventions for HUS and TTP in patients of all ages. We aimed to assess the interventions for HUS and TTP separately.

\section{METHODS}

\section{Criteria for considering studies for this review}

\section{Types of studies}

Studies eligible for inclusion in the review included all randomised controlled trials (RCTs) and quasi-RCTs (studies in which allocation to treatment group was obtained by alternation e.g. use of alternate medical records, date of birth or other predictable methods) which compared an intervention with placebo, an intervention with supportive therapy, or one or more different interventions for HUS or TTP.

\section{Types of participants}

\section{Inclusion criteria}

Studies, which included previously healthy patients of all ages fulfilling the diagnostic criteria for either HUS or TTP, were included.

- HUS was defined as acute onset of renal impairment (oliguria or anuria with elevated serum urea and creatinine), thrombocytopenia (platelet count $<150 \times 10^{9} / \mathrm{L}$ ), and microangiopathic haemolytic anaemia (haemoglobin $<10 \mathrm{~g} / \mathrm{dL}$ with microscopic evidence of fragmented red blood cells in a peripheral blood smear).

- TTP was defined as acute onset of central nervous system abnormalities in association with thrombocytopenia, microangiopathic haemolytic anaemia, fever, and renal impairment (with a variable range of severity). 
Studies in which $\geq 75 \%$ subjects had renal impairment and/ or CNS abnormalities, thrombocytopenia and microangiopathic haemolytic anaemia were eligible for inclusion in this review.

\section{Exclusion criteria}

Patients with septicaemia, known CKD, collagen or vascular disorders, or pre-existing malignant hypertension were excluded.

\section{Types of interventions}

Interventions compared with placebo or supportive therapy including dialysis (haemodialysis or peritoneal dialysis) or a comparison of two or more interventions were examined. Interventions examined included heparin, aspirin/dipyridamole, prostanoids, ticlopidine, vincristine, fresh-frozen plasma (FFP) infusion, plasmapheresis with FFP or cryosupernatant plasma (CSP), systemic corticosteroids, Shiga toxin binding agents or immunosuppressive agents.

\section{Types of outcome measures}

For patients with TTP the principal outcome of interest was failure of response to therapy, defined as failure of remission at or less than two weeks and at one month. Other outcomes of interest included all-cause mortality, and relapse rate during the follow up period (more than two months). For patients with HUS, the principal outcome of interest was all cause mortality. Other outcomes of interest included ESKD; renal biopsy changes (cortical necrosis, glomerular thrombotic microangiopathy and arterial thrombotic microangiopathy), persistent proteinuria, hypertension and CKD (glomerular filtration rate of $<80 \mathrm{~mL} / \mathrm{min} / 1.73 \mathrm{~m}^{2}$ ) at the last followup. Other outcomes of interest in both groups of patients (TTP and HUS) were extra renal manifestations of disease. Adverse effects of treatment such as bleeding, opportunistic infections and allergic reactions to the intervention were also of interest.

The definition of response or remission rate was that defined by the study investigators. This was usually improvement of platelet count $>150 \times 109 / \mathrm{L}$ for three consecutive days with or without resolution of haemolysis and normalisation of serum creatinine. Proteinuria was defined as the presence of $>2+$ protein on urinalysis or $>4 \mathrm{mg} /$ $\mathrm{m}^{2} / \mathrm{h}$ protein in a 24 hour urine sample. Hypertension was defined as systolic and diastolic blood pressure over 95 th centile for the age and height.

\section{Search methods for identification of studies}

\section{Electronic searches}

1. The Cochrane Renal Group's specialised register and the Cochrane Central Register of Controlled Trials (CENTRAL) in The Cochrane Library (Issue 4, 2008). CENTRAL and the Renal Groups specialised register contain the handsearched results of conference proceedings from general and speciality meetings. This is an ongoing activity across the Cochrane Collaboration and is both retrospective and prospective (Master List 2007). Please refer to The Cochrane Renal Group's Module in The Cochrane Library for the most up-to-date list of conference proceedings (Renal Group 2008).

2. MEDLINE (1966 to June 2006) using the optimally sensitive strategy developed for the Cochrane Collaboration for the identification of RCTs (Dickersin 1994 with a search strategy developed with input from the Cochrane Renal Groups Trial Search Co-ordinator.
3. EMBASE (1980 to June 2006) using a search strategy adapted from that developed for the Cochrane Collaboration for the identification of RCTs (Lefebvre 1996) with a search strategy developed with input from the Cochrane Renal Groups Trial Search Co-ordinator.

\section{Searching other resources}

Other sources searched included reference lists of textbooks, reviews, previous studies and conference proceedings of the International Paediatric Nephrology Association, the American Society of Nephrology, the International Congress of Nephrology and the European, Dialysis and Transplantation Association. Authors of identified studies were contacted to see if they knew of unpublished studies. Studies in languages other than English were translated and included and duplicate publications of the same study were identified through reading the articles in question and contacting the authors.

\section{Data collection and analysis}

\section{Study selection}

Three authors (MM, EE, GR) independently screened the titles and abstracts of the literature search and assessed study eligibility against defined inclusion criteria. This process favoured overselection in order to include all relevant studies. The full article was retrieved if uncertainty existed or when the abstract was not available. Any disagreement about article selection was resolved through discussion.

\section{Methodological quality assessment}

The three authors assessed the quality of included studies independently without blinding to authorship or journal of publication using the checklist developed for the Cochrane Renal Group. Discrepancies were resolved by consensus. The quality items assessed were allocation concealment, intention-to-treat analysis, completeness of follow-up and blinding of investigators, participants and outcome assessors (Hollis 1999; Moher 1998; Schulz 1995).

\section{Data extraction}

From all included studies, three authors extracted data using a standardised form. Study date and place, participant characteristics, intervention (type of treatment, dose, duration, cointerventions), comparator and primary and secondary outcomes of interest were recorded. When appropriate, authors of primary studies were contacted for clarification of data and to obtain missing information. Any discrepancies in data extraction were resolved in discussion. When results of a study were published more than once, the most complete data were extracted from all sources and used in the analysis only once. For dichotomous outcomes, results were expressed as risk ratio (RR) with 95\% confidence intervals $(\mathrm{Cl})$. Data were pooled using a random effects model whenever appropriate, but the fixed effects model was also analysed to ensure robustness and susceptibility to outliers. Mean difference (MD) with $95 \% \mathrm{Cl}$ was used where continuous scales of measurement were used to assess the effects of treatment. Statistical heterogeneity was analysed using the Cochran $Q$ test on $\mathrm{N}-1$ degrees of freedom, with an alpha of 0.1 used for statistical significance and 12 statistics with $>10 \%$ for statistical significance (Higgins 2003). There were insufficient studies to explore possible sources of variability. 


\section{RESULTS}

\section{Description of studies}

Of the 771 articles identified by an extensive literature search, after review of the title and abstracts by two authors, 688 were excluded (Figure 1). The reasons for exclusion were nonrandomised design, case reports, non-interventional studies and duplicate publications. Of the 83 full text articles reviewed, 15 eligible studies were identified (Bobbio-Pallavicini 1997; Henon 1992; Loirat 1984; Loirat 1988; Perez 1998; Rizzoni 1988; Rock 1991; Rock 2005; Roethele 2000; Trachtman 2003; Van Damme-
Lombaerts 1988; Vitacco 1973; Ziegler 2001). Of these, six studies (Bobbio-Pallavicini 1997; Henon 1992; Perez 1998; Rizzoni 1988; Rock 1991; Rock 2005; Roethele 2000; Ziegler 2001) compared different interventions in patients with TTP and were included. Nine studies compared different interventions in children with HUS and seven of these studies (Loirat 1984; Loirat 1988; Perez 1998; Rizzoni 1988; Trachtman 2003; Van Damme-Lombaerts 1988; Vitacco 1973) was included. Two of the nine HUS studies identified were published only in an abstract form and excluded because insufficient outcome data were available (Muller-Wiefel 1989; Thomson 1987). 
Figure 1. Flowchart of study selection

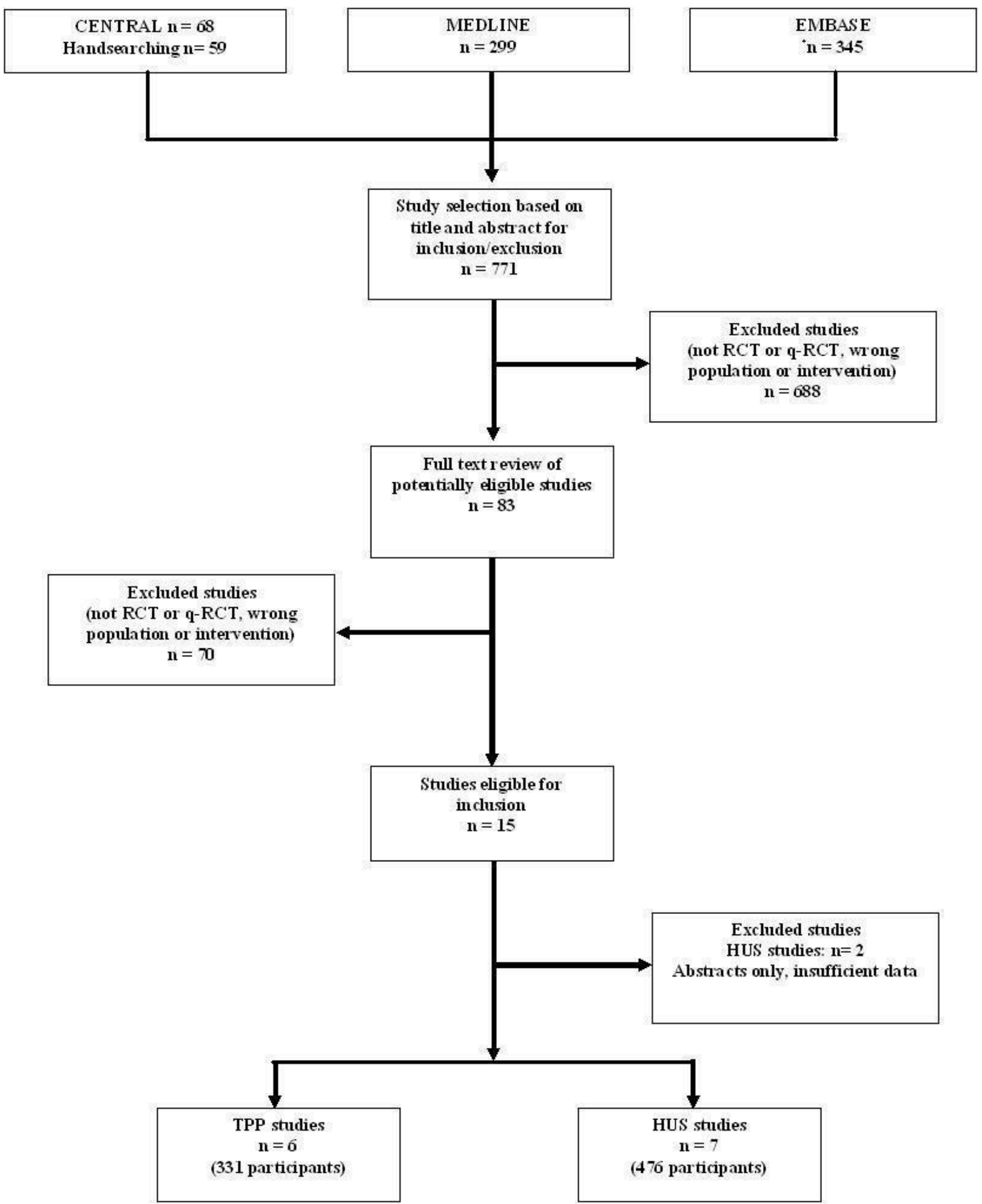


Characteristics of the population and intervention of included studies are presented in Characteristics of included studies. Of six included studies on interventions for TTP (331 patients), Roethele 2000 (35 patients) included patients with HUS or TTP (age 18 to 80 years) and insufficient data were provided to enable us to separate these groups. Because all patients included in this study were aged over 18 years, it is likely that most had TTP or atypical HUS, so this study was included with TTP studies for the purpose of this review. In all these six studies the main comparator (control) treatment was PE using FFP. In three studies (116 patients) PE with FFP was compared with CSP or cryoprecipitate poor plasma (CPP). In two studies (143 patients) PE with FFP was compared with FFP transfusion and in these studies both treatment and control groups also received antiplatelet therapy (APT), namely aspirin and dipyridamole. In one study (72 patients) effectiveness of APT was tested, the control group received PE with FFP plus steroid and the treatment group received with PE with FFP plus steroid plus APT for 15 days. The patients who responded by achieving remission from the APT group received ticlopidine for one year. For $5 / 6$ studies the follow-up period was more than six months.

Of the 476 patients in the seven included studies evaluating interventions for HUS, most were young children with postdiarrhoeal (typical) HUS $>70 \%$ in three studies (Loirat 1988; Rizzoni 1988; Van Damme-Lombaerts 1988), $100 \%$ in two studies (Perez 1998; Trachtman 2003), not reported in two studies (Loirat 1984; Vitacco 1973). None of these studies reported outcomes separately for children with typical and atypical HUS. In all HUS studies supportive therapy plus a specific intervention (treatment group) was compared with supportive therapy alone (control group). Supportive therapy generally included control of fluid and electrolyte imbalance, use of dialysis if required, control of hypertension and blood transfusion as required. In five of the seven studies peritoneal dialysis (PD) was used when dialysis was indicated but in two studies the type of dialysis used was not specified. A range of interventions was studied, including heparin with or without urokinase or dipyridamole (three studies, 121 patients); FFP infusion (two studies, 111 patients); methylprednisolone (one study, 94 patients) and shigatoxin binding agent called Synsorb-Pk (one study, 150 patients).

\section{Risk of bias in included studies}

\section{TTP studies}

- Allocation concealment was unclear in two (33\%) and adequate in four $(67 \%)$ studies.

- Blinding of participants, investigators and outcome assessors was not stated in any of the six studies.

- In two (33\%) studies intention-to-treat analysis was used.

- Between $0 \%$ and $10 \%$ participants were lost to follow up in five $(83 \%)$ studies and $49 \%$ in one (17\%) study.

\section{HUS studies}

- Allocation concealment was unclear in two $(29 \%)$ and adequate in five $(71 \%)$ studies.

- Participants and investigators were blinded in two $(29 \%)$ studies but blinding was not reported in five $(71 \%)$ studies. The outcome assessor was blinded in one (14\%) study but not reported in five $(86 \%)$ studies.

- Intention-to-treat analysis was used in five (71\%) studies.
- Between $0 \%$ and $5 \%$ were only lost to follow-up in all seven $(100 \%)$ studies.

\section{Effects of interventions}

\section{TTP studies}

In all studies involving patients with TTP, PE with FFP was used as the control. Interventions tested included with CPP or CSP, PI and APT. Initially we used meta-analysis to compare any interventions with PE with FFP and found no significant difference between the treatment and control groups in failure of remission at one month (Analysis 1.2 (4 studies, 140 patients): RR 1.19, 95\% Cl 0.71 to 2.00); all-cause mortality (Analysis 1.3 (6 studies, 309 patients): RR $0.96,95 \% \mathrm{Cl} 0.45$ to 2.08); and relapse rate (Analysis 1.4 (4 studies, 126 patients): RR $0.78,95 \% \mathrm{Cl} 0.39$ to 1.58 ). However, failure of remission at two weeks was significantly higher in the intervention group than the control group ( (Analysis 1.1 (4 studies, 264 patients): RR $1.36,95 \% \mathrm{Cl} 1.06$ to 1.74 ). There was significant heterogeneity between studies for most outcomes, which was expected considering the variety of interventions used. However there was no significant heterogeneity among the studies included in the meta-analysis for failure of remission at two weeks $\left(X^{2}=2.34\right.$, $\left.P=0.50 ; I^{2}=0 \%\right)$ and relapse rate $\left(X^{2}=3.28, P=0.35 ; I^{2}=9 \%\right)$.

Further meta-analysis was performed including only studies using the same interventions. Three studies (Rock 2005; Roethele 2000; Ziegler 2001) (116 patients) compared the use of PE with CSP or CPP to PE with FFP. Failure of remission at two weeks (Analysis 2.1) and one month (Analysis 2.2) was reported only in one of these studies; all-cause mortality was reported for three studies (Analysis 2.3); and relapse rate was reported in two studies (Analysis 2.4). There was no significant difference between PE with FFP and PE with CSP/CPP for any of the four outcomes of interest. There was no significant heterogeneity between the studies.

In two TTP studies (Henon 1992; Perez 1998) (140 patients), PI with FFP plus APT was compared with PE with FFP plus APT. The failure of remission at $<2$ weeks was significantly higher in the PI group (Analysis 3.1 (2 studies, 140 patients): RR 1.48, 95\% 1.12 to 1.96). In addition, all-cause mortality was significantly higher in the PI group (Analysis 3.3 (2 studies, 140 patients): RR 1.91, 95\% 1.09 to 3.33). Failure of remission rate at one month (Analysis 3.2 (2 studies, 72 patients): RR $1.50,95 \% \mathrm{Cl} 0.93$ to 2.42 ) and relapse rate (Analysis 3.4 (2 studies, 99 patients): RR $0.34,95 \% \mathrm{Cl} 0.10$ to 1.15) was not significantly different between control and treatment groups. There was no significant heterogeneity between the studies for any of these reported outcomes.

In Bobbio-Pallavicini 1997 the effect of APT was tested in patients with TTP. Aspirin and dipyridamole were used for 15 days and patients in the treatment arm who had gone into remission were then treated with ticlopidine for one year. Both the treatment and control groups received PE with FFP and steroid. There was no significant difference between the two groups with regard to failure of remission at 2 weeks (Analysis 4.1) or at one month (Analysis 4.2), or in all-cause mortality (Analysis 4.3) and relapse rate (Analysis 4.4).

Side effects of treatment were reported in only $2 / 6$ TTP studies. In Bobbio-Pallavicini 1997 which used APT, 4/35 patients from the APT arm had transient worsening of pre-existing bleeding but none of the nonbleeding patients experienced any bleeding. 
In addition, 2/32 patients from ticlopidine group developed severe erosive gastritis that resolved with medical treatment. In Rock 1991, which compared PI with PE, 6/51 patients in the PE group and 5/51 patients in PI group reported no complications. The remaining patients from both groups all experienced minor complications, including nausea, hypotension, tachycardia, tachypnoea, dizziness, chills or oedema. In addition, eight of these had bleeding and four patients in each group had seizures during the procedure.

\section{HUS studies}

In the studies, that included patients with HUS, supportive therapy (control group) was compared with a range of interventions including anticoagulation therapy, FFP infusion, steroid and a Shiga toxin binding agent. None of the tested interventions were superior to supportive therapy alone (Analysis 5.1, Analysis 5.2, Analysis 5.3, Analysis 5.4).

In three studies (Loirat 1984; Van Damme-Lombaerts 1988; Vitacco 1973) anticoagulation therapy was used (heparin alone in one study, heparin and urokinase in one study, and heparin and dipyridamole in one study. In all these studies the treatment and control groups received supportive therapy. There was no significant difference between the groups for any of the primary or secondary outcomes including all-cause mortality (Analysis 6.1), neurological events (Analysis 6.2), renal biopsy changes (Analysis 6.3, Analysis 6.4), proteinuria (Analysis 6.5) or hypertension (Analysis 6.6) at the last follow-up. However, the incidence of bleeding was significantly higher in the group that received anticoagulation therapy compared to supportive therapy alone (Analysis 6.8 (3 studies, 124 patients): RR 25.89, 95\% Cl 3.67 to 182.83). There was no heterogeneity between the studies for this outcome $\left(X^{2}=0.02, I^{2}=0 \%\right)$. Nineteen $(33 \%)$ of 58 children who received an anticoagulant but none of 66 children in the control group experienced bleeding.

Because $1 / 3$ studies had no bleeding events, the relative frequency was not estimable. We therefore looked at risk difference (RD) to investigate the difference in event rates. When the random effects model was used there was no significant difference between the two groups (Analysis 6.9: RD $0.44,95 \% \mathrm{Cl}-0.39$ to 1.28 ), however when we used the fixed effect model the difference was significant (Analysis 6.10: RD $0.35,95 \% \mathrm{Cl} 0.25$ to 0.45 ). It is important to highlight these significant differences in bleeding rates between the two interventions under study, however, the imprecision caused by zero event rates and the significant heterogeneity $\left(X^{2}=132.22, I^{2}=\right.$ $98 \%)$ should be considered when interpreting this result.

In two studies (Loirat 1988; Rizzoni 1988) (117 patients) FFP infusion was compared with supportive therapy. There was no significant difference between the two groups for any of the outcomes of interest (Analysis 7.1, Analysis 7.2, Analysis 7.3, Analysis 7.4). Perez 1998 (94 patients) compared steroids with placebo and there was no significant difference between the two groups for any of the outcome measures of interest (Analysis 8.1, Analysis 8.2, Analysis 8.3). Trachtman 2003 compared shiga toxin binding agent (Synsorb-Pk) and placebo (145 patients) (comparison 09). There was no significant difference between the two groups for any of the outcome measures of interest (Analysis 9.1, Analysis 9.2, Analysis 9.3, Analysis 9.4, Analysis 9.5). Subgroup analysis performed according to study quality, year of the study (before and after 1990) and type of HUS (diarrhoea associated or typical versus atypical) did not demonstrate any differences in treatment effects for the outcome of all cause mortality in the HUS studies.

Side effects of treatment were reported in five studies. As reported above, rates of bleeding were significantly higher in patients receiving anticoagulation. In one study that compared supportive therapy plus steroid with supportive therapy and placebo, the number of cases of peritonitis was similar between groups. In Rizzoni 1988, which compared PI with supportive therapy, PI had to be stopped after seven days in one child due to cardiac overload. This study also reported non-A non-B hepatitis in two children from the control group but none from PI group.

\section{DISCUSSION}

This is the systematic review of the literature for RCTs evaluating interventions for HUS or TTP. We have shown that PE with FFP is more effective than FFP alone in patients with TTP and that other interventions provide no significant additional benefit over PE with FFP with regard to any of the outcomes of interest (failure of remission, all-cause mortality and relapse rate) from any of the interventions tested in RCTs (PE with CSP or CPP; PI and APT; or PE with FFP and APT).

PE with CSP or CPP in three studies conferred no advantage over PE with FFP for outcomes of interest. Although use of CSP may incur additional cost, none of the studies compared the difference in cost involved with the use of CSP or CPP as opposed to FFP. In one study, which used APT reported slightly increased risk of bleeding and gastritis in the APT group but no significant difference for any of the four outcomes of interest.

Based on the results of this systematic review, use of PE with FFP remains the primary treatment of choice for patients with TTP. Alternative therapies confer no additional benefit but increased risk. Some patients with TTP require prolonged PE to prevent a fatal outcome and to achieve a sustained remission. In these patients adjunct treatments including immunosuppressive agents such as corticosteroids, vincristine, cyclophosphamide, azathioprine, cyclosporin A, high dose intravenous immunoglobulin, staphylococcal protein A, immunoadsorption or splenectomy have been used with variable results (Crowther 1996; Durand 1992; Udvardy 1990). However, we found no RCTs testing the effectiveness of any of these interventions. Use of rituximab, an anti-CD20 monoclonal antibody, has shown promise in a small prospective cohort study in patients with acute refractory and severe relapsing TTP related to anti-ADAMTS13 antibodies (Fakhouri 2005). The transfusion Medicine/Haemostasis (TMH) Clinical Trials Network from North America have initiated a RCT comparing the effectiveness of early use of rituximab versus placebo in addition to $P E$ and glucocorticoids (George 2006).

For HUS, we found that FFP, anticoagulation therapy, steroids and Shiga toxin binding agent confer no advantage over supportive therapy alone for any of the outcomes; all-cause mortality, neurological/extra renal events, ESRD, renal biopsy changes or proteinuria, and hypertension at the last follow-up. Adverse effects were reported in 5/7 included studies and bleeding was significantly higher with anticoagulation therapy in the three studies which compared its effectiveness. In the majority of the studies (5/7) peritoneal dialysis was used when dialysis was indicated. This contrasts with current practice in the majority of the 
North American centres where the preferred mode is haemodialysis or continuous venovenous haemodiafiltration (CVVHD) for the management of acute kidney injury (Maxvold 2003). Our findings likely reflect the age of the studies included in the review, as 5/7 studies were published before 1990 and one before 2000 .

It is important to note that in $5 / 7$ HUS studies, included predominantly children with post-diarrhoeal HUS $>70 \%$ in three studies, $100 \%$ in two studies, not reported in two studies) and that no papers reported outcomes separately for children with diarrhoea-associated (typical) and atypical HUS. It has been suggested in the literature that atypical cases have a worse outcome. In two studies, in which FFP infusion was compared with supportive therapy, there was no significant difference between the treatment and control groups for any of the outcomes of interest. However, the majority ( $>70 \%)$ of patients in both studies had postdiarrhoeal HUS, which usually remits with supportive therapy. The effectiveness of PE was tested in Muller-Wiefel 1989, which was not included in this systematic review as it was published only in an abstract form and data regarding outcomes of interest for this review were not available. This study failed to show any superior response on incidence of recurrence or ESKD in their small subset of high-risk patients.

Based on the results of this systematic review, supportive therapy (including blood transfusion, control of fluid and electrolyte imbalance, dialysis when indicated and control of hypertension) remains the preferred management for patients with postdiarrhoeal HUS. However, we identified only a small number of studies, many of them old and none comparing the effectiveness of different types of dialysis (peritoneal dialysis, haemodialysis or (VVHD) in patients with acute kidney injury due to HUS. We found no RCTs that evaluated the effectiveness of any interventions including $\mathrm{PI}$ or $\mathrm{PE}$ in patients with atypical HUS, who may have a more chronic and relapsing course and present with features similar to TTP. Atypical HUS is not a homogeneous condition but has several different aetiologies and is a rare disease. Hence multicentre studies in well-characterised patients would be required to evaluate specific treatments.

Limitations of this review include the small number, suboptimal methodological quality and age of included studies, the possibility of publication bias, the small number of participants with atypical HUS, and the failure to separate atypical and typical HUS in recruitment and reporting of studies.

\section{AUTHORS' CONCLUSIONS}

\section{Implications for practice}

Results of this review suggest, for patients with TTP early use of PE with FFP remains as the primary treatment of choice and alternative therapies confer no additional benefit but increased risk. And for patients with HUS, supportive therapy including blood transfusion, control of fluid and electrolyte imbalance, dialysis when indicated and control of hypertension, remains as the primary treatment of choice. Majority of the studies used peritoneal dialysis (5/7 studies and 2/7 studies did not mention the type of dialysis used) when dialysis was indicated which might reflect the age of the studies as 5/7 studies were conducted before 1990 . Hence there is no data to support the use of any one particular type of dialysis. As majority of the studies included diarrhoea positive HUS (typical HUS) patients and since we were unable to separate the data between the typical and atypical HUS, there is no data to suggest whether PI is useful in atypical HUS patients.

\section{Implications for research}

Studies to look at effectiveness of novel therapies may be needed to improve outcome for TTP and HUS. Especially RCTs that evaluate the effectiveness of any interventions including PI or PE in patients with atypical HUS, who may have a more chronic and relapsing course and present with features similar to TTP are needed. As atypical HUS is a rare disease, multicentre studies in wellcharacterised patients would be required to evaluate specific treatments.

\section{ACKNOWLEDGEMENTS}

The authors thank Narelle Willis, Review Group Coordinator of the Cochrane Renal Group, Ruth Mitchell, Trials Search Coordinator of the Cochrane Renal Group, and Ms Sunita Chauhan, Research Librarian at the Centre for Evidence Based Paediatrics, Gastroenterology and Nutrition, Sydney for their help with this study which was carried out for the Cochrane Collaboration. Abstract of this review was accepted for poster presentation at the 14th Congress of the International Pediatric Nephrology Association in August 2007.

This study was undertaken as part of the thesis work for the Master of Medicine (Clinical Epidemiology) program undertaken by Mini Michael and she acknowledges the support of a scholarship received for her from the Centre for Clinical Research Excellence (CCRE) in Renal Medicine, Sydney Australia to undertake this program. Elizabeth Elliott is supported by a National Health and Medical Research Council of Australia Practitioner Fellowship (No. 457084). 


\section{RE F E R E N C E S}

\section{References to studies included in this review}

Bobbio-Pallavicini 1997 \{published data only\}

Bobbio-Pallavicini E, Gugliotta L, Centurioni R, Porta C, Vianelli N, Billio A, et al. Antiplatelet agents in thrombotic thrombocytopenic purpura (TTP). Results of a randomized multicenter trial by the Italian Cooperative Group for TTP. Haematologica 1997;82(4):429-35. [MEDLINE: 9299856]

Henon 1992 \{published data only\}

Henon P. Thrombotic thrombocytopenic purpura: Clinical results of a French controlled trial. Transfusion Science 1992;13(1):63-72. [EMBASE: 1992108633]

\section{Loirat 1984 \{published data only\}}

Loirat C, Beaufils E, Sonsino N, Schlegel M, Guesnu G, Pillon JL, et al. Treatment of childhood hemolytic-uremic syndrome with urokinase. Cooperative controlled trial. Archives Francaises de Pediatrie 1984;41(1):15-9. [MEDLINE: 6372729]

Loirat 1988 \{published data only\}

Loriat C, Sonsino E, Hinglais N, Jais JP, Landais P, Fermanian J. Treatment of the childhood haemolytic uraemic syndrome with plasma. A multicentre randomized controlled trial. The French Society of Paediatric Nephrology. Pediatric Nephrology 1988;2(3):279-85. [MEDLINE: 3153025]

Perez 1998 \{published data only\}

Perez N, Spizzirri F, Rahman R, Suarez A, Larrubia C, Lasarte P. Steroids in the hemolytic uremic syndrome. Pediatric Nephrology 1998;12(2):101-4. [MEDLINE: 9543364]

Rizzoni 1988 \{published data only\}

Rizzoni G, Claris-Appiani A, Edefonti A, Facchin P, Franchini F, Gusmano R, et al. Plasma infusion for hemolytic-uremic syndrome in children: results of a multicenter controlled trial. Journal of Pediatrics 1988;112(2):284-90. [MEDLINE: 3276865]

\section{Rock 1991 \{published data only\}}

Rock GA, Shumak KH, Buskard NA, Blanchette VS, Kelton JG, Nair RC, et al. Comparison of plasma exchange with plasma infusion in the treatment of thrombotic thrombocytopenic purpura. Canadian Apheresis Study Group. New England Journal of Medicine 1991;325(6):393-7. [MEDLINE: 2062330]

\section{Rock 2005 \{published data only\}}

Rock G, Anderson D, Clark W, Leblond P, Palmer D, Sternbach M, et al. Does cryosupernatant plasma improve outcome in thrombotic thrombocytopenic purpura? No answer yet. British Journal of Haematology 2005;129(1):79-86. [MEDLINE: 15801959]

\section{Roethele 2000 \{published data only\}}

Rothele E, Krumme B, Rump LC. Design of the prospective randomized study for the treatment of patients with thrombotic microangiopathy. PRODROMI Study Group. Therapeutic Apheresis 2000;4(5):327-31. [MEDLINE: 11111812]
Trachtman 2003 \{published data only\}

Trachtman H, Cnaan A, Christen E, Gibbs K, Zhao S, Acheson DW, et al. Effect of an oral Shiga toxin-binding agent on diarrhea-associated hemolytic uremic syndrome in children: a randomized controlled trial. JAMA 2003;290(10):1337-44. [MEDLINE: 12966125]

\section{Van Damme-Lombaerts 1988 \{published data only\}}

Van Damme-Lombaerts R, Proesmans W, Van Damme B, Eeckels R, Binda ki Muaka P, Mercieca V, et al. Heparin plus dipyridamole in childhood hemolytic-uremic syndrome: a prospective, randomized study. Journal of Pediatrics 1988;113(5):913-8. [MEDLINE: 3183852]

Vitacco 1973 \{published data only\}

Vitacco M, Sanchez Avalos J, Gianantonio CA. Heparin therapy in the hemolytic uremic syndrome. Journal of Pediatrics 1973;83(2):271-5. [MEDLINE: 4717585]

Ziegler 2001 \{published data only\}

Zeigler ZR, Shadduck RK, Gryn JF, Rintels PB, George JN, Besa EC, et al. Cryoprecipitate poor plasma does not improve early response in primary adult thrombotic thrombocytopenic purpura (TTP). Journal of Clinical Apheresis 2001;16(1):19-22. [MEDLINE: 11309826]

\section{References to studies excluded from this review}

Muller-Wiefel 1989 \{published data only\}

Muller-Wiefel DE, Bulla M, Klare B, Balzar R, Bambauer R, Tonshoff B. Efficacy of therapeutic plasma exchange in haemolytic uraemic syndrome in childhood [abstract]. Nephrology Dialysis Transplantation 1989;4(5):446. [CENTRAL: CN-00260427]

\section{Thomson 1987 \{published data only\}}

Thomson PD, Milnor LS. A randomly selected trial of vitamin $E$ in the haemolytic uraemic syndrome (HUS) [abstract]. Xth International Congress of Nephrology; 1987 Jul 26-31; London (UK). 1987:98.

\section{Additional references}

\section{Allford 2003}

Allford SL, Hunt BJ, Rose P, Machin SJ, Haemostasis and Thrombosis Task Force, British Committee for Standards in Haematology. Guidelines on the diagnosis and management of the thrombotic microangiopathic haemolytic anaemias. British Journal of Haematology 2003;120(4):556-73. [MEDLINE: 12588343]

\section{Banatvala 2001}

Banatvala N, Griffin PM, Greene KD, Barrett TJ, Bibb WF, Green JH, et al. The United States National Prospective Hemolytic Uremic Syndrome Study: microbiologic, serologic, clinical, and epidemiologic findings. Journal of Infectious Diseases 2001;183(7):1063-70. [MEDLINE: 11237831] 


\section{Bender 1997}

Bender JB, Hedberg CW, Besser JM, Boxrud DJ, MacDonald KL, Osterholm MT. Surveillance for Escherichia coli 0157:H7 infections in Minnesota by molecular subtyping. New England Journal of Medicine 1997;337(6):388-94. [EMBASE: 1997234878]

\section{Bianchi 2002}

Bianchi V, Robles R, Alberio L, Furlan M, Lammle B. Von Willebrand factor-cleaving protease (ADAMTS13) in thrombocytopenic disorders: a severely deficient activity is specific for thrombotic thrombocytopenic purpura. Blood 2002;100(2):710-3. [MEDLINE: 12091372]

\section{Bukowski 1976}

Bukowski RM, Hewlett JS, Harris JW, Hoffman GC, Battle JD Jr, Silverblatt $\mathrm{E}$, et al. Exchange transfusions in the treatment of thrombotic thrombocytopenic purpura. Seminars in Hematology 1976;13(3):219-32. [MEDLINE: 779037]

\section{Byrnes 1977}

Byrnes JJ, Khurana M. Treatment of thrombotic thrombocytopenic purpura with plasma. New England Journal of Medicine 1977;297(25):1386-9. [MEDLINE: 562982]

\section{Crowther 1996}

Crowther MA, Heddle N, Hayward CP, Warkentin T, Kelton JG. Splenectomy done during hematologic remission to prevent relapse in patients with thrombotic thrombocytopenic purpura. Annals of Internal Medicine 1996;125(4):294-6. [MEDLINE: 8678392]

\section{Decludt 2000}

Decludt B, Bouvet P, Mariani-Kurkdjian P, Grimont F, Grimont PA, Hubert B, et al. Haemolytic uraemic syndrome and Shiga toxin-producing Escherichia coli infection in children in France. Epidemiology \& Infection 2000;124(2):215-20. [MEDLINE: 10813145]

\section{Dickersin 1994}

Dickersin K, Scherer R, Lefebvre C. Identifying relevant studies for systematic reviews. BMJ 1994;309(6964):1286-91. [MEDLINE: 7718048]

\section{Durand 1992}

Durand JM, Lefevre P, Kaplanski G, Telle H, Soubeyrand J. Vincristine for thrombotic thrombocytopenic purpura. Lancet 1992;340(8825):977-8. [MEDLINE: 1357383]

\section{Elliott 2001}

Elliott EJ, Robins-Browne RM, O'Loughlin EV, BennettWood V, Bourke J, Henning P, et al. Nationwide study of haemolytic uraemic syndrome: clinical microbiological, and epidemiological features. Archives of Disease in Childhood 2001;85(2):125-31. [MEDLINE: 11466187]

\section{Fakhouri 2005}

Fakhouri F, Vernant JP, Veyradier A, Wolf M, Kaplanski G, Binaut $R$, et al. Efficiency of curative and prophylactic treatment with rituximab in ADAMTS13-deficient thrombotic thrombocytopenic purpura: a study of 11 cases. Blood 2005;106(6):1932-7. [MEDLINE: 15933059]

\section{Furlan 1998}

Furlan M, Robles R, Galbusera M, Remuzzi G, Kyrle PA, Brenner $\mathrm{B}$, et al. von Willebrand factor-cleaving protease in thrombotic thrombocytopenic purpura and the hemolyticuremic syndrome. New England Journal of Medicine 1998;339(22):1578-84. [MEDLINE: 9828245]

\section{George 2006}

George JN, Woodson RD, Kiss JE, Kojouri K, Vesely SK. Rituximab therapy for thrombotic thrombocytopenic purpura: a proposed study of the Transfusion Medicine/Hemostasis Clinical Trials Network with a systematic review of rituximab therapy for immune-mediated disorders. Journal of Clinical Apheresis 2006;21(1):49-56. [MEDLINE: 16619232]

\section{Higgins 2003}

Higgins JP, Thompson SG, Deeks JJ, Altman DG. Measuring inconsistency in meta-analyses. BMJ 2003;327(7414):557-60. [MEDLINE: 12958120]

\section{Hollis 1999}

Hollis S, Campbell F. What is meant by intention to treat analysis? Survey of published randomised controlled trials. BMJ 1999;319(7211):670-4. [MEDLINE: 10480822]

\section{Hosler 2003}

Hosler GA, Cusumano AM, Hutchins GM. Thrombotic thrombocytopenic purpura and hemolytic uremic syndrome are distinct pathologic entities. A review of 56 autopsy cases. Archives of Pathology \& Laboratory Medicine 2003;127(7):834-7. [MEDLINE: 12823037]

\section{Kaplan 1992}

Kaplan BS, Kaplan P. Hemolytic uremic syndrome in families. In: Kaplan BS, Trompeter R, Moake J editor(s). Hemolytic uremic syndrome and thrombotic thrombocytopenic purpura. New York: Marcel-Netter, 1995.

\section{Kaplan 1995}

Kaplin BS. Thrombotic microangiopathy: A proposal for a new terminology for hemolytic uremic syndrome and thrombotic thrombocytopenic purpura. Journal of Nephrology 1995;8:3-4.

\section{Lefebvre 1996}

Lefebvre C, McDonald S. Development of a sensitive search strategy for reports of randomized controlled trials in EMBASE. Fourth International Cochrane Colloquium; 1996 Oct 20-24; Adelaide (Australia). 1996.

\section{Martin 1990}

Martin DL, MacDonald KL, White KE, Soler JT, Osterholm MT. The epidemiology and clinical aspects of the hemolytic uremic syndrome in Minnesota. New England Journal of Medicine 1990;323(17):1161-7. [MEDLINE: 2215593]

\section{Maxvold 2003}

Maxvold NJ, Bunchman TE. Renal failure and renal replacement therapy. Critical Care Clinics 2003;19(3):563-75. [MEDLINE: 12848321] 


\section{Milford 1990}

Milford DV, Taylor CM, Gutteridge B, Hall SM, Rowe B, Kleanthous H. Haemolytic uraemic syndromes in the British Isles 1985-8: association with verocytotoxin producing Escherichia coli. Part 1: Clinical and epidemiological aspects. Archives of Disease in Childhood 1990;65(7):716-21. [MEDLINE: 2201261]

\section{Moher 1998}

Moher D, Pham B, Jones A, Cook DJ, Jadad AR, Moher M, et al. Does quality of reports of randomised trials affect estimates of intervention efficacy reported in meta-analyses. Lancet 1998;352(9128):609-13. [MEDLINE: 9746022]

\section{Neuhaus 1997}

Neuhaus T, Calonder S, Leumann E. Heterogeneity of atypical haemolytic uraemic syndromes. Archives of Disease in Childhood 1997;76(6):518-21. [MEDLINE: 9245850]

\section{Remuzzi 1995}

Remuzzi G, Ruggenenti P. The hemolytic uremic syndrome. Kidney International 1995;48(1):2-19. [MEDLINE: 7564079]

\section{Rock 1996}

Rock G, Shumak KH, Sutton DM, Buskard NA, Nair RC. Cryosupernatant as replacement fluid for plasma exchange in thrombotic thrombocytopenic purpura. Members of the Canadian Apheresis Group. British Journal of Haematology 1996;94(2):383-6. [MEDLINE: 8759902]

\section{Rowe 1991}

Rowe PC, Orrbine E, Wells GA, McLaine PN. Epidemiology of hemolytic-uremic syndrome in Canadian children from 1986 to 1988. The Canadian Pediatric Kidney Disease Reference Centre. Journal of Pediatrics 1991;119(2):218-24. [MEDLINE: 1861207]

\section{Ruggenenti 2001}

Ruggenenti P, Noris M, Remuzzi G. Thrombotic microangiopathy, hemolytic uremic syndrome, and thrombotic thrombocytopenic purpura. Kidney International 2001;60(3):831-46. [MEDLINE: 11532079]

\section{Sacher 1996}

Sacher R, Moake J. Solvent detergent-treated plasma versus fresh frozen plasma in patients with TTP. Transfusion 1996;36(Suppl 95):63S.

\section{Schulz 1995}

Schulz KF, Chalmers I, Hayes RJ, Altman DG. Empirical evidence of bias. Dimensions of methodological quality associated

\section{CHARACTERISTICS OF STUDIES}

Characteristics of included studies [ordered by study ID] with estimates of treatment effects in controlled trials. JAMA 1995;273(5):408-12. [MEDLINE: 7823387]

\section{Taylor 2001}

Taylor CM. Hemolytic-uremic syndrome and complement factor H deficiency: clinical aspects. Seminars in Thrombosis \& Hemostasis 2001;27(3):185-90. [MEDLINE: 11446651]

\section{Torok 1995}

Torok TJ, Holman RC, Chorba TL. Increasing mortality from thrombotic thrombocytopenic purpura in the United States analysis of national mortality data, 1968-1991. American Journal of Hematology 1995;50(2):84-90. [MEDLINE: 7573005]

\section{Tsai 1998}

Tsai HM, Lian EC. Antibodies to von Willebrand factor-cleaving protease in acute thrombotic thrombocytopenic purpura. New England Journal of Medicine 1998;339(22):1585-94. [MEDLINE: 9828246]

\section{Udvardy 1990}

Udvardy M, Rak K. Cyclophosphamide for chronic relapsing thrombotic thrombocytopenic purpura. Lancet 1990;336(8729):1508-9. [MEDLINE: 1979115]

\section{Vesely 2003}

Vesely SK, George JN, Lammle B, Studt JD, Alberio L, El-Harake MA, et al. ADAMTS13 activity in thrombotic thrombocytopenic purpura-hemolytic uremic syndrome: relation to presenting features and clinical outcomes in a prospective cohort of 142 patients. Blood 2003;102(1):60-8. [MEDLINE: 12637323]

\section{References to other published versions of this review Elliott 2002}

Elliott E, Ridley G, Hodson E, Craig J. Interventions for haemolytic uraemic syndrome and thrombotic thrombocytopenic purpura. Cochrane Database of Systematic Reviews 2002, Issue 2. [DOI: 10.1002/14651858.CD003595]

\section{Michael 2008}

Michael M, Elliott EJ, Craig JC, Ridley G, Hodson EM. Interventions for hemolytic uremic syndrome and thrombotic thrombocytopenic purpura: A systematic review of randomized controlled trials. American Journal of Kidney Diseases 2008:in press.

Bobbio-Pallavicini 1997

$\begin{array}{ll}\text { Methods } & \text { Country: Italy } \\ & \text { Recruitment: Multicentre, Italian Cooperative Group } \\ & \text { Random allocation: Yes } \\ & \text { Blinding }\end{array}$

Interventions for haemolytic uraemic syndrome and thrombotic thrombocytopenic purpura (Review) 
Bobbio-Pallavicini 1997 (Continued)

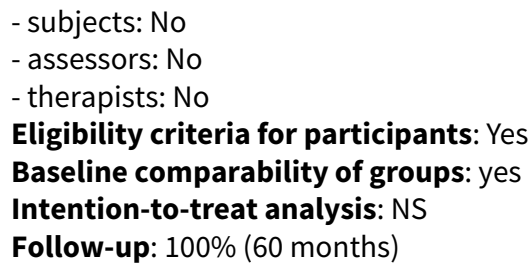

Participants

\section{Inclusion criteria}

- Adults with TTP (platelet count < $100 \times 10^{9} / \mathrm{L}$, microangiopathic haemolytic anaemia, high lactate dehydrogenase, low haptoglobin)

- Age (mean \pm SD)

- Males: $39.6 \pm 15.4$ years

- Females: $37.3 \pm 15.7$ years

- $\operatorname{Sex}(M / F): 25 / 47$

\section{Treatment group}

Number: 35

\section{Control group}

Number: 37

- PE: 7 to 10 sessions, with at least 7 sessions in the first 10 days

- Methylprednisolone (2 mg/kg/d IV)

- Acetylsalicylic acid or lysine salicylate

- Dypyridamole (3 mg/kg/d orally or $0.4 \mathrm{mg} / \mathrm{kg} / \mathrm{d}$ IV)

\section{Control group}

- PE plus methylprednisolone

- Assessment of disease status at 15 days

- Patients who achieved full remission were treated with APT (ticlopidine $(500 \mathrm{mg} / \mathrm{d})$ for 1 year). Patients who achieved partial remission were scheduled to receive 7 more PEs and, if complete remission was not achieved, were given high dose IgG $(0.4 \mathrm{~g} / \mathrm{kg} / \mathrm{d}$, for 5 days). If complete remission was still not achieved, patients were treated as non-responders (given salvage treatment of choice: vincristine, PGI2, high-dose IgG, or splenectomy)

- Placebo: no

$\begin{array}{ll}\text { - } & \text { Failure of remission at } 2 \text { weeks } \\ \text { - Failure of remission at } 1 \mathrm{month} \\ \text { - All-cause mortality } \\ \text { - Relapse rate } \\ \text { - Disease status at } 15 \text { days: Complete remission: (platelets }>150 \times 109 / \mathrm{L} \text {, reticulocytes }<100 \times 109 / \mathrm{L}, \mathrm{LDH} \\ & <300 \mathrm{U} / \mathrm{L} \text {, serum BUN }<50 \mathrm{mg} \% \text { and creatinine } 1.2 \mathrm{mg} \%)\end{array}$

Notes $\quad$ TTP study

\section{Risk of bias}

\begin{tabular}{lll}
\hline Bias & Authors' judgement & Support for judgement \\
\hline Allocation concealment? & Low risk & A - Adequate \\
\hline
\end{tabular}


Henon 1992

\begin{tabular}{ll}
\hline Methods & Country: France \\
Recruitment: Multicentre \\
Randomisation: Central \\
Blinding \\
- - $u$ - asjects: NS \\
- therapists: NS \\
Intention-to-treat analysis: No \\
Follow-up: $100 \%$ (12 months) \\
Inclusion criteria \\
- Adults with TTP \\
- 28 French natives, 9 natives of other Mediterranean countries. \\
- Five patients with cancer (3 treated with mitomycin C and diagnosed with TTP) \\
- 5 cases developed due to incorrect treatment with ticlopidine (3), aspirin (2) for venous thrombosis \\
and 3 cases with cimetidine. \\
- Pregnancy (2), oral contraceptives (8), tobacco (12), alcoholism (2). Only $37 \%$ patients presented with \\
triad of haemorrhage, neurological symptoms, renal impairment. All patients however presented all \\
eligibility criteria at some point in their clinical course.
\end{tabular}

Males/age: 14, median 35 years (range: 19-62)

Females/age: 25, median 39 years (range: $18-57$ )

\section{Treatment group}

Number: 19

Control group

Number: 19

Interventions Treatment group

- Daily PE with FFP (15 mL/kg) in albumin $(45 \mathrm{~mL} / \mathrm{kg})$ until complete remission achieved.

\section{Control group}

- Daily transfusion of FFP (15 mL/kg) until complete remission achieved

Both groups received aspirin ( $10 \mathrm{~mL} / \mathrm{kg} / \mathrm{d})$ plus dipyridamole $(10 \mathrm{mg} / \mathrm{kg} / \mathrm{d})$.

If treatment or control failed, a common regime of PE with FFP $(60 \mathrm{~mL} / \mathrm{kg} / \mathrm{d})$ tried. After a second failure, salvage therapy (splenectomy, steroids, vincristine, infusion of PGI2), alone or in various combinations, could be tried

\begin{tabular}{ll}
\hline Outcomes & Failure of remission at 2 weeks \\
- & Failure of remission at 1 month \\
- & All-cause mortality \\
- & Relapse rate \\
- & Complete remission (normalisation of clinical biochemical parameters) \\
\hline Notes & TTP study \\
- Post randomisation exclusions & $* 2$ patients, 1 from treatment (due to death prior to treatment) and 1 from control group(due to \\
& wrong diagnosis)
\end{tabular}

\section{Risk of bias}


Henon 1992 (Continued)
Allocation concealment?
Unclear risk
B - Unclear

Loirat 1984

\begin{tabular}{ll}
\hline Methods & Country: France \\
Recruitment: Multicentre \\
Random allocation: yes \\
Blinding \\
- subjects: NS \\
- assessors: NS \\
- therapists: NS \\
Intention-to-treat analysis: NS \\
Eligibility criteria: Yes \\
Baseline characteristics of participants: Yes \\
Follow-up: $100 \%$ (42 months)
\end{tabular}

\begin{tabular}{ll}
\hline Participants & - French children with HUS \\
& - Most under 3 years
\end{tabular}

Treatment group

Number: 15

Control group

Number: 18

Interventions

\title{
Treatment group
}

- Urokinase and heparin plus supportive care

\section{Control group}

- Support care alone

Supportive care was similar in both groups (PD if dialysis indicated).

$\begin{array}{ll}\text { - } & \text { All-cause mortality } \\ \text { - Proteinuria at last follow-up } & \text { - Hypertension at last follow-up } \\ \text { - Adverse events: bleeding }\end{array}$

Notes $\quad$ HUS study

\section{Risk of bias}

\begin{tabular}{lll}
\hline Bias & Authors' judgement & Support for judgement \\
\hline Allocation concealment? & Unclear risk & B - Unclear \\
\hline
\end{tabular}

\section{Loirat 1988}

Methods

\author{
Country: France \\ Recruitment: Multicentre study (19 units) involving French Society of Paediatric Nephrology \\ Random allocation: yes, stratified by centre \\ Eligibility criteria: Yes \\ Baseline characteristics of participants: Similar
}


Loirat 1988 (Continued)

\author{
Blinding \\ - subjects: NS \\ - assessors: NS \\ - therapists: NS \\ Intention-to-treat analysis: Yes \\ Follow-up: 100\% (short-term); 75\% (12 months)
}

\begin{tabular}{|c|c|}
\hline Participants & $\begin{array}{l}\text { Inclusion criteria } \\
\text { - Median age: } 19 \text { months (range } 2 \text { months to } 13 \text { years) } \\
\text { - Sex: } 40 \text { males } \\
\text { Treatment group } \\
\text { Number: } 39 \\
\text { Control group } \\
\text { Number: } 40\end{array}$ \\
\hline Interventions & $\begin{array}{l}\text { Treatment group } \\
\text { - FFP } 10 \mathrm{~mL} / \mathrm{kg} / \mathrm{d} \text { for } 7 \text { days plus supportive care } \\
\text { Control group } \\
\text { - Supportive care only } \\
\text { Supportive care was similar in both groups (PD if indicated) }\end{array}$ \\
\hline Outcomes & $\begin{array}{l}\text { - All-cause mortality } \\
\text { - ESKD (dialysis-dependent at } 6 \text { weeks) } \\
\text { - Proteinuria at last follow-up } \\
\text { - Hypertension at last follow-up }\end{array}$ \\
\hline Notes & $\begin{array}{l}\text { - HUS study } \\
\text { - Diarrhoea prodrome: } 87 \%\end{array}$ \\
\hline Risk of bias & \\
\hline Bias & Authors' judgement Support for judgement \\
\hline Allocation concealment? & Low risk \\
\hline
\end{tabular}

\title{
Perez 1998
}

Methods

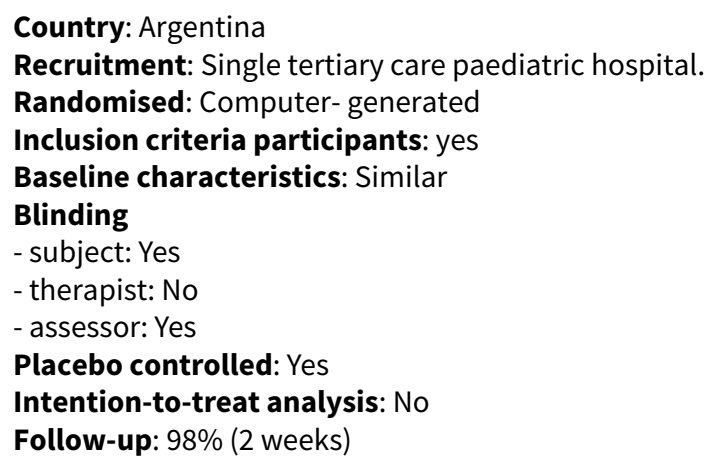

Participants Inclusion criteria


Perez 1998 (Continued)

- Sex: 48 males

- Median age: 13 months (range 9-23)

- Groups were similar at study entry (age, sex, seizure history, haematology, biochemistry)

\section{Treatment group}

Number: 45

\section{Control group}

Number: 47

\begin{tabular}{ll}
\hline Interventions & Treatment group \\
& - Methylprednisolone $(5 \mathrm{mg} / \mathrm{kg} / \mathrm{d}), 4$ times a day for 7 days \\
& Cupportive care \\
& Control group \\
& - Placebo (matched for colour, flavour appearance) \\
& - Supportive care \\
& Supportive interventions similar in both groups (type of dialysis not specified) \\
\hline Outcomes & All-cause mortality \\
& - Neurological event \\
\hline Notes & Adverse events: peritonitis \\
\hline Risk of bias & HuS study \\
\hline Bias & Diarrhoea-associated HUS (100\%) \\
\hline Allocation concealment? & Low risk \\
\hline
\end{tabular}

\section{Rizzoni 1988}

Country: Italy
Recruitment: Multicentre (4 paediatric Nephrology Departments)
Randomisation: Centrally, stratified for age (<3 or $>3$ years)
Inclusion criteria for participants: Yes
Baseline characteristics: Similar
Blinding
- subjects: NS
- therapists: NS
- assessors: NS
Intention-to-treat analysis: Yes
Follow-up: $100 \%$ (16 months)

\section{Participants}

\section{Inclusion criteria}

- Sex/age

* 16 males mean age 2.5 years (range 4 months to 6.5 years)

* 21 males $<3$ years

- Matched at entry for age, season, diarrhoea prodrome, haematological and renal function

\section{Treatment group}


Rizzoni 1988 (Continued)

Number: 17

\section{Control group}

Number: 15

\begin{tabular}{ll}
\hline Treatment group \\
- FFP infusion ( $30 \mathrm{~mL} / \mathrm{kg})$. Day 1 , over at least 3 hours and $10 \mathrm{~mL} / \mathrm{kg} / \mathrm{d}$ thereafter \\
- $\mathrm{Pl}$ stopped 3 days after the platelet count had normalised $(>150,000 \mathrm{U} / \mathrm{L}$ for 3 consecutive days) and \\
haematocrit and haemoglobin levels had stabilised \\
- When no haematological response, PI were stopped after 15 to 20 days \\
- Supportive care \\
Control group \\
- Supportive care only \\
Supportive care similar in both groups (type of dialysis not specified). \\
\hline - All-cause mortality \\
- ESKD (dialysis-dependent at 6 weeks) \\
- Proteinuria at last follow-up \\
- Hypertension at last follow-up \\
- HUS study \\
- Diarrhoea prodrome: $72 \%$
\end{tabular}

\section{Risk of bias}

\begin{tabular}{lll}
\hline Bias & Authors' judgement & Support for judgement \\
\hline Allocation concealment? & Low risk & A- Adequate \\
\hline
\end{tabular}

Rock 1991

$\begin{array}{ll}\text { Country: Canada } & \text { Recruitment: Multicentre, 16 participating medical centres } \\ \text { Rethods } & \text { Randomisation: Stratified (initially, then discontinued) followed by allocation of patients to treatment } \\ & \text { Blinding } \\ & \text { - subjects: NS } \\ & \text { - therapists: NS } \\ & \text { - assessors: NS } \\ & \text { Intention-to-treat: Until end of first cycle (2 weeks). Patients then allowed to crossover treatment } \\ & \text { arms and reassessed at } 6 \text { months } \\ & \text { Inclusion criteria } \\ & \text { Sex (M/F): } 35 / 67 \\ & \text { Mean age: } 40.5 \text { years (SD 14.3) } \\ \text { Participants } & \text { Treatment group } \\ & \text { Number: } 51 \\ & \text { Control group } \\ & \text { Number: } 51\end{array}$


Rock 1991 (Continued)

- PI with FFP ( $30 \mathrm{~mL} / \mathrm{kg} / \mathrm{d} \times 1$ day, then $15 \mathrm{~mL} / \mathrm{kg}$ each day thereafter) until end of first cycle of treatment (9 days) or until an event at which time patient taken off treatment (which for patients on PI meant transfer to PE)

\section{Control group}

- PE with FFP (1.5x the predicted plasma volume for first 3 procedures and $1 x$ the predicted volume thereafter) for a minimum of 7 procedures over the first 9 days

All patients received dipyridamole $(400 \mathrm{mg} / \mathrm{d})$ and aspirin $(325 \mathrm{mg} / \mathrm{d})$ orally for 2 weeks after entry

\begin{tabular}{ll}
\hline Outcomes & - Failure of remission at 2 weeks \\
& - Failure of remission after 2 weeks \\
& - All-cause mortality \\
\hline Notes & Relapse rate \\
\hline
\end{tabular}

\section{Risk of bias}

\begin{tabular}{lll}
\hline Bias & Authors' judgement & Support for judgement \\
\hline Allocation concealment? & Low risk & A - Adequate \\
\hline
\end{tabular}

\section{Rock 2005}

\begin{tabular}{|c|c|}
\hline Methods & $\begin{array}{l}\text { Country: Canada } \\
\text { Recruitment: Patients from nine centres } \\
\text { Randomisation: Random number generation at a central site } \\
\text { Blinding } \\
\text { - subjects: NS } \\
\text { - therapists: NS } \\
\text { - assessors: NS } \\
\text { Intention-to-treat analysis: Yes } \\
\text { Follow-up: } 100 \% \text { ( } 6 \text { months) }\end{array}$ \\
\hline Participants & $\begin{array}{l}\text { Treatment group } \\
\text { Number: } 28 \\
\text { Control group } \\
\text { Number: } 24\end{array}$ \\
\hline Interventions & $\begin{array}{l}\text { Treatment group } \\
\text { - PE x } 1.5 \text { plasma volume with CSP for } 2 \text { sessions, the } \times 1 \text { plasma volume for } 5 \text { days plus optional APT } \\
\text { with dipyridamole } 400 \mathrm{mg} / \mathrm{d} \text { orally and aspirin } 325 \mathrm{mg} / \mathrm{d} \text { for a minimum of } 2 \text { weeks } \\
\text { Control Group } \\
\text { - PE } \times 1.5 \text { plasma volume with FFP for } 2 \text { sessions and then } \times 1 \text { plasma volume for } 5 \text { days plus optional APT }\end{array}$ \\
\hline Outcomes & $\begin{array}{l}\text { - Failure of remission at } 2 \text { weeks } \\
\text { - Failure of remission } 1 \text { month } \\
\text { - All-cause mortality }\end{array}$ \\
\hline Notes & - TTP study \\
\hline
\end{tabular}


Rock 2005 (Continued)

\section{Risk of bias}

\begin{tabular}{lll}
\hline Bias & Authors' judgement & Support for judgement \\
\hline Allocation concealment? & Low risk & A - Adequate \\
\hline
\end{tabular}

Roethele 2000

\begin{tabular}{ll}
\hline Methods & Country: Germany \\
Recruitment: Multicentre study \\
Randomisation: Block randomisation stratified by centre (maximum block size =10) \\
Blinding \\
- subjects: No \\
- therapists: No \\
- assessors: NS \\
Intention-to-treat analysis: NS \\
Inclusion criteria for participants: Yes \\
Baseline characteristics: NS \\
Follow-up: $100 \%$ (24 months)
\end{tabular}

Follow-up: $100 \%$ (24 months)

\begin{tabular}{|c|c|}
\hline Participants & $\begin{array}{l}\text { Age: } 18-80 \text { years } \\
\text { Treatment group } \\
\text { Number: } 20 \\
\text { Control group } \\
\text { Number: } 15\end{array}$ \\
\hline Interventions & $\begin{array}{l}\text { Treatment group } \\
\text { - PE with CSP } \\
\text { Control group } \\
\text { - PE with FFP } \\
\text { A minimum of } 5 \text { and a maximum of } 10 \text { treatments were given till platelet count was }>150,000 / \mu \mathrm{L} \text {. } \\
\text { All patients initially received methylprednisolone }(1.5 \mathrm{mg} / \mathrm{kg} \text { orally or IV for } 5 \text { days, then tapered by } 0.2 \\
\mathrm{mg} / \mathrm{kg} / \mathrm{d})\end{array}$ \\
\hline Outcomes & $\begin{array}{l}\text { - All-cause mortality } \\
\text { - Relapse rate }\end{array}$ \\
\hline Notes & $\begin{array}{l}\text { - } \text { TTP study } \\
\text { - All patients were }>18 \text { years, this study was included as a TTP study for this review }\end{array}$ \\
\hline Risk of bias & \\
\hline Bias & Authors' judgement Support for judgement \\
\hline Allocation concealment? & A - Adequate \\
\hline
\end{tabular}

Methods Country: USA


Trachtman 2003 (Continued)

Recruitment: Phase III RCT of SYNSORB Pk in children with E. coli-associated HUS.

\section{Blinding}

- subjects: Yes

- therapists: Yes

- assessors: NS

Intention-to-treat: No

Follow-up: 2 months

\section{Participants}

\section{Inclusion criteria}

- Children of both sexes

- Median age: 4.2 years (range 2.4 -6.8 years)

- E. coli-associated diarrhoea-associated HUS and diarrhoea of less than 7 days duration

- HUS defined as thrombocytopenia (platelets $<130,000 / \mathrm{mm}^{3}$ ), fragmented red blood cells and acute renal failure with haematuria, proteinuria or azotaemia

\section{Treatment group}

Number: 96

\section{Control Group}

Number: 49

\section{Exclusion criteria}

- Children with hereditary HUS, HIV infection, pre-existing structural or motility disorder of the gastrointestinal tract, chronic inflammatory bowel disease, HUS associated with transplantation, Streptococcus pneumoniae infection; prior catastrophic complications of $E$. coli infection; underlying renal glomerular disease

Treatment group
Interventions

\section{Risk of bias}

\begin{tabular}{lll}
\hline Bias & Authors' judgement & Support for judgement \\
\hline Allocation concealment? & Low risk & A - Adequate \\
\hline
\end{tabular}




Country: Belgium
Recruitment: Paediatric department at one hospital
Randomisation: Randomly assigned by previously prepared, numbered and closed envelopes Treat-
ment groups balanced in blocks of 20.
Blinding
- subjects: NS
- therapists: NS
- assessors: NS
Intention-to-treat: Yes
Follow-up: 60 months

\begin{tabular}{|c|c|}
\hline Participants & $\begin{array}{l}\text { Inclusion criteria } \\
\text { - Sex (M/F): } 26 / 32 \\
\text { - Age range: } 6-13 \text { weeks, } 26<2 \text { years } \\
\text { Treatment group } \\
\text { Number: } 30 \\
\text { Control group } \\
\text { Number: } 28\end{array}$ \\
\hline Interventions & $\begin{array}{l}\text { Treatment group } \\
\text { - Heparin (starting dose: } 200 \mathrm{U} / \mathrm{kg} \text { IV followed by additional doses to keep activated partial thrombo- } \\
\text { plastin time at twice the normal value) } \\
\text { - Dipyridamole ( } 0.5 \mathrm{mg} / \mathrm{kg} \text { IV twice daily) until remission } \\
\text { - Supportive treatment } \\
\text { Control group } \\
\text { - Supportive treatment only } \\
\text { Supportive treatment similar in both groups (PD if indicated). }\end{array}$ \\
\hline Outcomes & $\begin{array}{l}\text { - All-cause mortality } \\
\text { - Neurological event } \\
\text { - Hypertension at last follow-up } \\
\text { - Adverse events: bleeding }\end{array}$ \\
\hline Notes & $\begin{array}{l}\text { - HUS study } \\
\text { - Diarrhoea-associated HUS: } 85 \%\end{array}$ \\
\hline
\end{tabular}

\section{Risk of bias}

\begin{tabular}{lll}
\hline Bias & Authors' judgement & Support for judgement \\
\hline Allocation concealment? & Low risk & A - Adequate \\
\hline
\end{tabular}

\section{Vitacco 1973}

$\begin{array}{ll}\text { Methods } & \text { Country: Argentina } \\ & \text { Randomisation: Method NS } \\ & \text { Blinding } \\ & \text { - subjects: NS }\end{array}$


Vitacco 1973 (Continued)

\author{
- therapists: NS \\ - assessors: NS \\ Intention-to-treat analysis: NS \\ Follow-up: 100\% (2 months)
}

Inclusion criteria
Participants
- Children with severe HUS (defined as anuria or sustained convulsions and/or coma, profuse gastroin-
testinal bleeding and/or retinal haemorrhages, serum potassium $>7.5 \mathrm{mEq} / \mathrm{L}$, diastolic blood pres-
sure $>90 \mathrm{~mm} \mathrm{Hg}$ )
- Baseline characteristics (age, oliguric period) similar
- Mean age: 1 year ( $0.3-3.0$ years)

\title{
Treatment group
}

Number: 10

Control group

Number: 20

\begin{tabular}{ll}
\hline Interventions & Treatment group \\
- Heparin priming dose of $1 \mathrm{mg} / \mathrm{kg}$ body weight intravenously adjusted to keep coagulation time three \\
times above initial values \\
- Duration of treatment mean 9 days (3-17 days); given within 12 to 36 hours after admission \\
- Supportive therapy \\
Control group \\
- Supportive therapy \\
Supportive therapy similar in both groups (including PD if required) \\
\hline - All-cause mortality \\
- Adverse effect bleeding \\
- HUS study \\
- Only children with severe/complicated HUS were included. A third group of children with HUS ( $\mathrm{n}=$ \\
3) given heparin after randomisation due to deterioration in condition they were not included in the \\
analysis for this review
\end{tabular}

\section{Risk of bias}

\begin{tabular}{lll}
\hline Bias & Authors' judgement & Support for judgement \\
\hline Allocation concealment? & Unclear risk & B - Unclear \\
\hline
\end{tabular}

\section{Ziegler 2001}

$\begin{array}{ll}\text { Methods } & \text { Country: North America } \\ & \text { Recruitment: Multicentre, North American TTP group including hospitals, University Depts (7) } \\ & \text { Randomisation: in a prospective fashion } \\ & \text { Blinding } \\ & \text { - subjects: NS } \\ \text { - therapists: NS } \\ \text { - assessors: NS } \\ \text { Intention-to-treat: No } \\ \text { Follow-up: }<1 \text { month }\end{array}$


Ziegler 2001 (Continued)

\section{Participants}

\section{Treatment group}

- Number: 14

- Sex M/F): $4 / 10$

- Median age: 45 years (IQ range 35-51)

\section{Control group}

- Number: 13

- $\operatorname{Sex}(M / F): 5 / 8$

- Median age: 38 years (IQ range 28-53)

No significant difference between age, sex, TTP score, haemoglobin, platelets, creatinine, LDH levels.

\section{Exclusion criteria}

- Patients with a blood pressure $<90$ systolic, prothrombin time or partial thromboplastin time $>$ than $1.5 x$ lab mean and a fibrinogen $<100 \mathrm{mg} \%$.

- Pregnancy, active malignancy, known HIV positivity, history of IgA deficiency and splenomegaly

\section{Treatment group}

- Daily PE $(60 \mathrm{~mL} / \mathrm{kg}$ ) with replacement using CPP (plasma from which cryoprecipitate fraction had been removed)

\section{Control group}

- Daily PE (60 mL/kg) with FFP).

All patients also received steroid therapy (methylprednisolone $0.75 \mathrm{mg} / \mathrm{kg}$ IV every 12 hours), which was tapered off over 2 weeks regardless of response. Patients analysed for clinical parameters on day 1,6 and 13 of therapy. Once a complete response sustained for at least 2 successive days, PE was tapered to every other day for 3 times, then to every 3rd day for 2 times, then held. If platelets fell to $<150$ $\mathrm{K} / \mu \mathrm{L}$, daily PE and corticosteroids reinitiated. Patients who showed progression of TTP were treated off study.

\begin{tabular}{|c|c|c|}
\hline Outcomes & $\begin{array}{l}\text { - All-cause mortality } \\
\text { - Relapse rate }\end{array}$ & \\
\hline Notes & - TTP study & \\
\hline \multicolumn{3}{|l|}{ Risk of bias } \\
\hline Bias & Authors' judgement & Support for judgement \\
\hline Allocation concealment? & Unclear risk & B - Unclear \\
\hline
\end{tabular}

APT: anti-platelet drug therapy; CSP: cryosupernatant plasma; ESKD: end-stage kidney disease; FFP: fresh-frozen plasma; HUS: haemolytic uraemic syndrome; NS: not stated; PD: peritoneal dialysis; PE: plasma exchange; PI: plasma infusion; TTP: thrombocytopenic purpura

Characteristics of excluded studies [ordered by study ID]

\begin{tabular}{ll}
\hline Study & Reason for exclusion \\
\hline Muller-Wiefel 1989 & $\begin{array}{l}\text { Published only in abstract form, not enough data available for the outcomes of interest; Unsuc- } \\
\text { cessful attempt to obtain more data. } \\
\text { RCT, method of randomisation not specified. }\end{array}$ \\
\hline
\end{tabular}




\begin{tabular}{ll}
\hline Study & Reason for exclusion \\
\hline Thomson 1987 & $\begin{array}{l}\text { Published only in abstract form, not enough data available for the outcomes of interest; Unsuc- } \\
\text { cessful attempt to obtain more data. } \\
\text { RCT, method of randomisation not specified. }\end{array}$ \\
\hline
\end{tabular}

\section{DATA AND ANALYSES}

Comparison 1. TTP studies: Any intervention versus plasma exchange (PE) with fresh-frozen plasma (FFP)

\begin{tabular}{llllll}
\hline Outcome or subgroup title & $\begin{array}{l}\text { No. of } \\
\text { studies }\end{array}$ & $\begin{array}{l}\text { No. of } \\
\text { partici- } \\
\text { pants }\end{array}$ & Statistical method & Effect size \\
\hline 1 Failure of remission at 2 weeks & 4 & 264 & Risk Ratio (M-H, Random, 95\% Cl) & $1.36[1.06,1.74]$ \\
\hline 2 Failure of remission at 1 month & 4 & 140 & Risk Ratio (M-H, Random, 95\% Cl) & $1.19[0.71,2.00]$ \\
\hline 3 All-cause mortality & 6 & 309 & Risk Ratio (M-H, Random, 95\% Cl) & $0.96[0.45,2.08]$ \\
\hline 4 Relapse rate & 4 & 126 & Risk Ratio (M-H, Random, 95\% Cl) & $0.78[0.39,1.58]$ \\
\hline
\end{tabular}

Analysis 1.1. Comparison 1 TTP studies: Any intervention versus plasma exchange

(PE) with fresh-frozen plasma (FFP), Outcome 1 Failure of remission at 2 weeks.

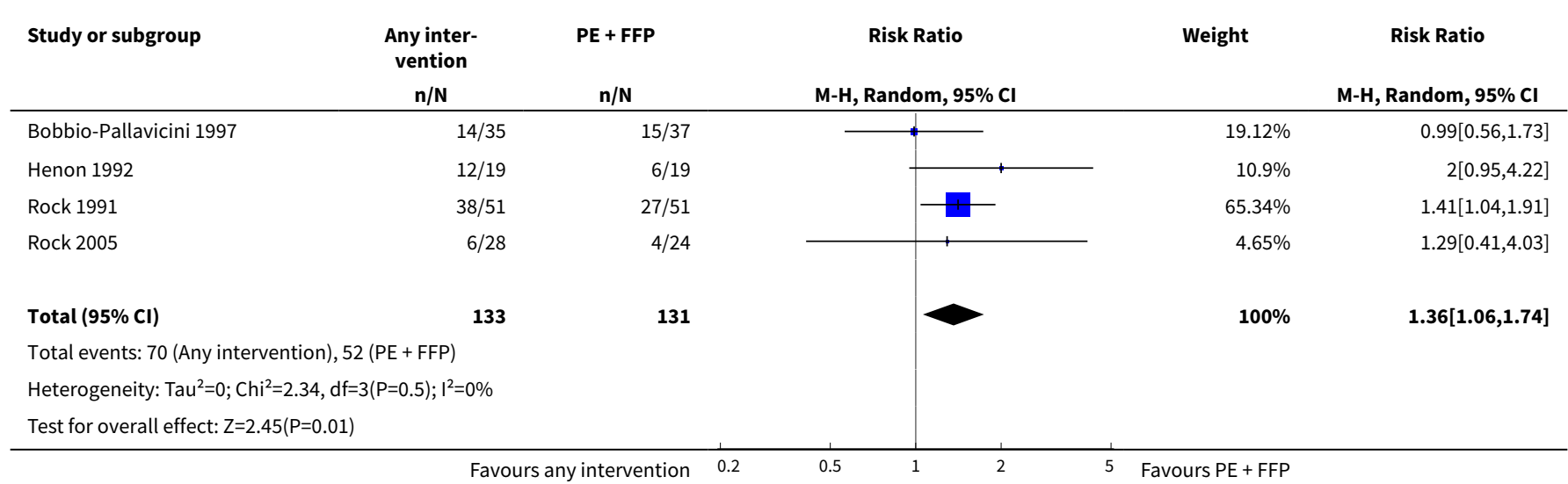

Analysis 1.2. Comparison 1 TTP studies: Any intervention versus plasma exchange

(PE) with fresh-frozen plasma (FFP), Outcome 2 Failure of remission at 1 month.

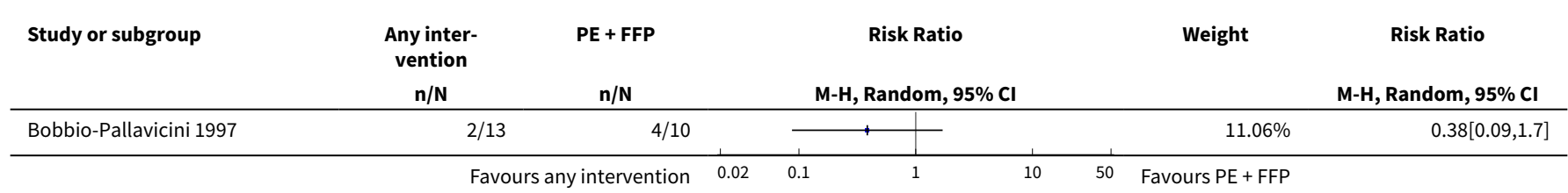




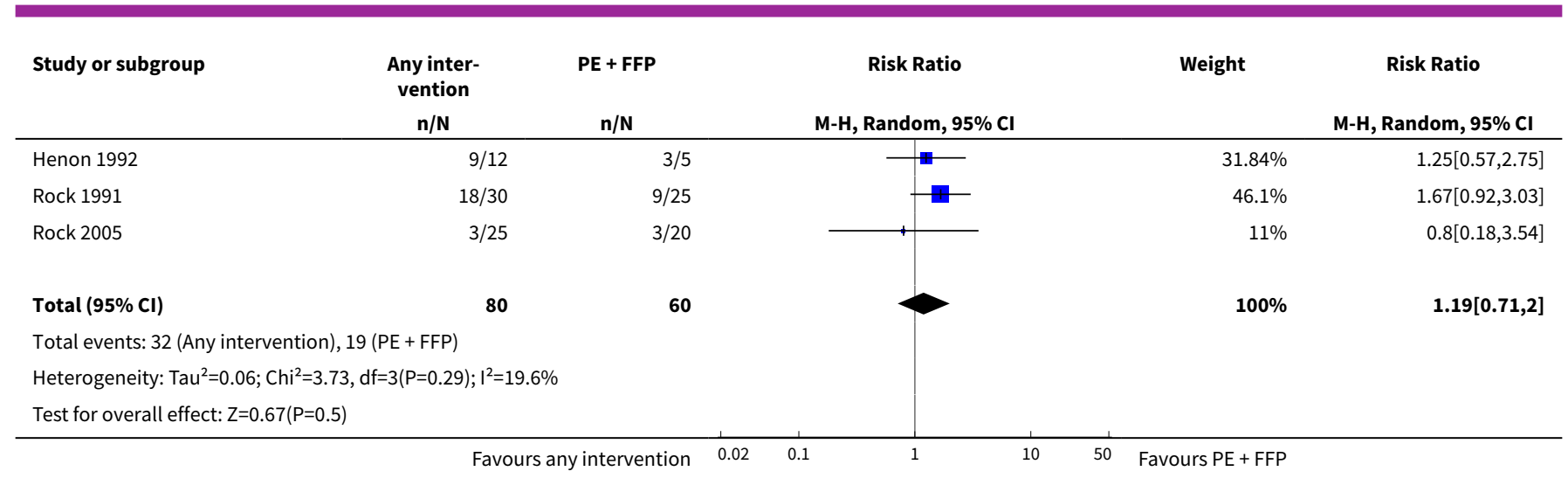

Analysis 1.3. Comparison 1 TTP studies: Any intervention versus plasma exchange (PE) with fresh-frozen plasma (FFP), Outcome 3 All-cause mortality.

\begin{tabular}{|c|c|c|c|c|c|}
\hline \multirow[t]{2}{*}{ Study or subgroup } & $\begin{array}{l}\text { Any inter- } \\
\text { vention }\end{array}$ & \multirow{2}{*}{$\begin{array}{c}\text { PE + FFP } \\
n / N\end{array}$} & \multirow[b]{2}{*}{ M-H Random 95\% CI } & \multirow[t]{2}{*}{ Weight } & \multirow{2}{*}{$\begin{array}{c}\text { Risk Ratio } \\
\text { M-H, Random, } 95 \% \mathrm{Cl}\end{array}$} \\
\hline & $n / N$ & & & & \\
\hline Bobbio-Pallavicini 1997 & $3 / 35$ & $9 / 37$ & $\longrightarrow$ & $19.14 \%$ & $0.35[0.1,1.2]$ \\
\hline Henon 1992 & $8 / 19$ & $3 / 19$ & 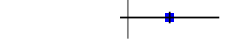 & $20.03 \%$ & $2.67[0.83,8.55]$ \\
\hline Rock 1991 & $19 / 51$ & $11 / 51$ & $\rightarrow$ & $29.61 \%$ & $1.73[0.92,3.25]$ \\
\hline Rock 2005 & $1 / 28$ & $2 / 24$ & $\longrightarrow$ & $8.38 \%$ & $0.43[0.04,4.44]$ \\
\hline Ziegler 2001 & $3 / 14$ & $3 / 13$ & - & $16.49 \%$ & $0.93[0.23,3.81]$ \\
\hline Total $(95 \% \mathrm{Cl})$ & 154 & 155 & & $100 \%$ & $0.96[0.45,2.08]$ \\
\hline \multicolumn{6}{|c|}{ Total events: 34 (Any intervention), 32 (PE + FFP) } \\
\hline \multicolumn{6}{|c|}{ Heterogeneity: $\mathrm{Tau}^{2}=0.42 ; \mathrm{Chi}^{2}=9.99, \mathrm{df}=5(\mathrm{P}=0.08) ; \mathrm{I}^{2}=49.93 \%$} \\
\hline Test for overall effect: $Z=$ & & & & & \\
\hline
\end{tabular}

Analysis 1.4. Comparison 1 TTP studies: Any intervention versus plasma exchange (PE) with fresh-frozen plasma (FFP), Outcome 4 Relapse rate.

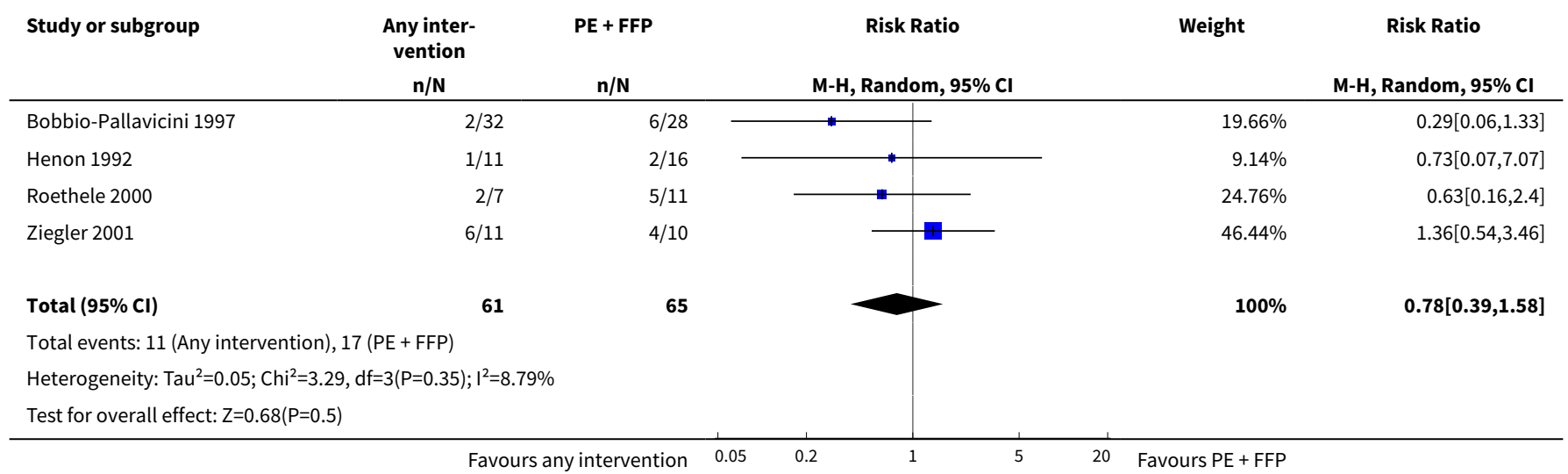


Comparison 2. TTP studies: Plasma exchange (PE) with cryosupernatant plasma (CSP) or cryoprecipitate poor plasma (CPP) versus plasma exchange with fresh-frozen plasma (FFP)

\begin{tabular}{lllll}
\hline Outcome or subgroup title & $\begin{array}{l}\text { No. of } \\
\text { studies }\end{array}$ & $\begin{array}{l}\text { No. of } \\
\text { partici- } \\
\text { pants }\end{array}$ & Statistical method & Effect size \\
\hline 1 Failure of remission <2 weeks & 1 & & Risk Ratio (M-H, Random, 95\% Cl) & Totals not selected \\
\hline 2 Failure of remission at 1 month & 1 & Risk Ratio (M-H, Random, 95\% Cl) & Totals not selected \\
\hline 3 All-cause mortality & 3 & 97 & Risk Ratio (M-H, Random, 95\% Cl) & $0.59[0.20,1.80]$ \\
\hline 4 Relapse rate & 2 & 39 & Risk Ratio (M-H, Random, 95\% Cl) & $1.06[0.49,2.27]$ \\
\hline
\end{tabular}

Analysis 2.1. Comparison 2 TTP studies: Plasma exchange (PE) with cryosupernatant plasma (CSP) or cryoprecipitate poor plasma (CPP) versus plasma exchange with fresh-frozen plasma (FFP), Outcome 1 Failure of remission $<2$ weeks.

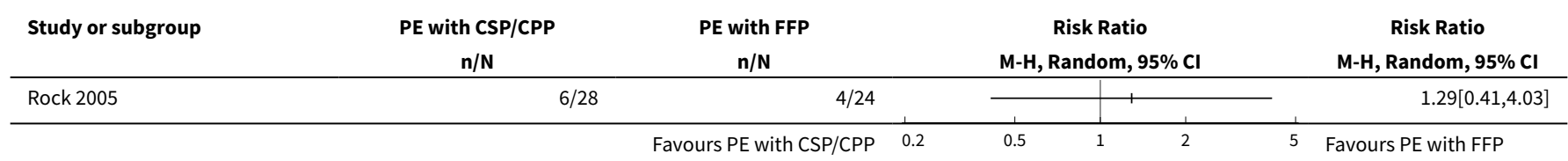

Analysis 2.2. Comparison 2 TTP studies: Plasma exchange (PE) with cryosupernatant plasma (CSP) or cryoprecipitate poor plasma (CPP) versus plasma exchange with fresh-frozen plasma (FFP), Outcome 2 Failure of remission at 1 month.

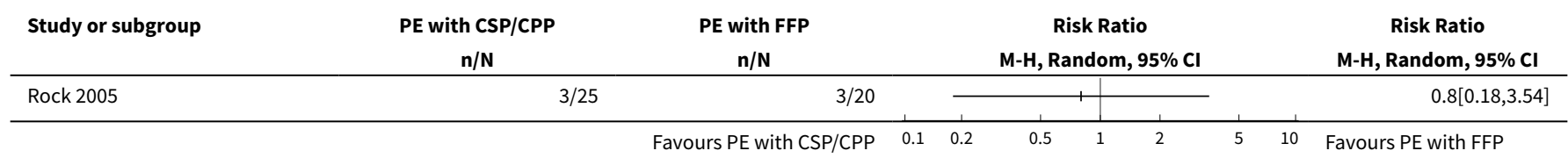

Analysis 2.3. Comparison 2 TTP studies: Plasma exchange (PE) with cryosupernatant plasma (CSP) or cryoprecipitate poor plasma (CPP) versus plasma exchange with fresh-frozen plasma (FFP), Outcome 3 All-cause mortality.

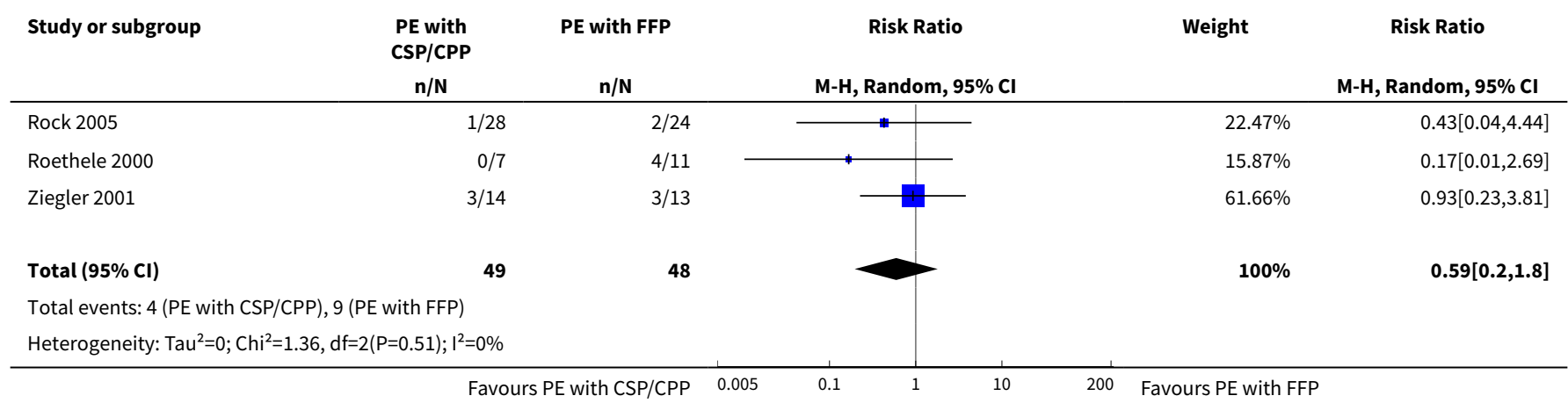




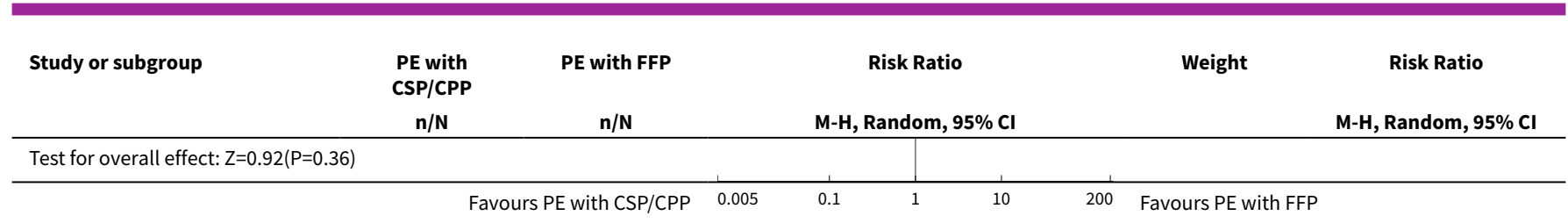

Analysis 2.4. Comparison 2 TTP studies: Plasma exchange (PE) with cryosupernatant plasma (CSP) or cryoprecipitate poor plasma (CPP) versus plasma exchange with fresh-frozen plasma (FFP), Outcome 4 Relapse rate.

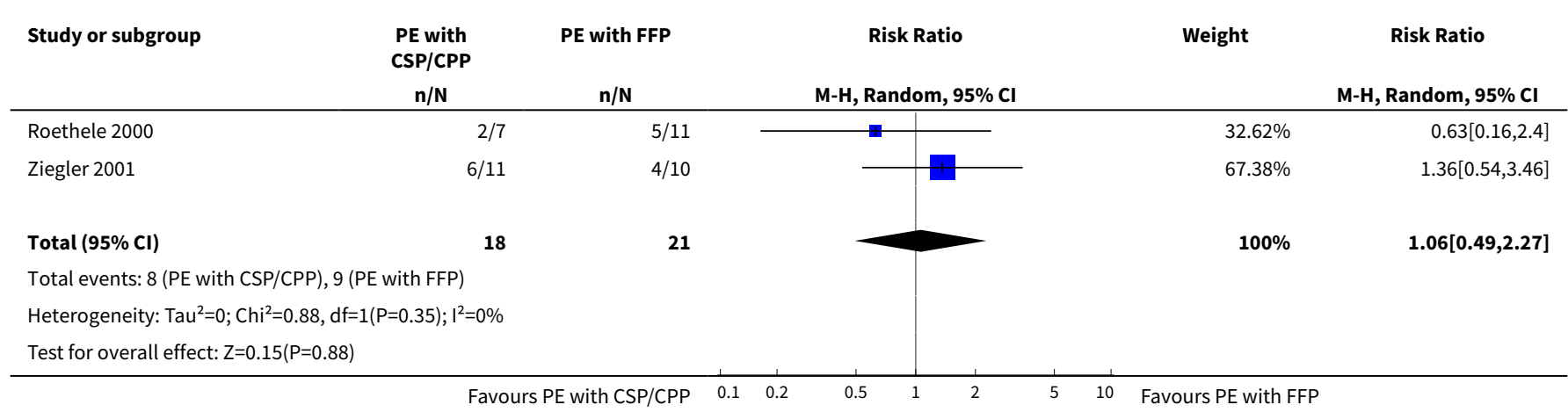

Comparison 3. TTP studies: Plasma infusions (PI) plus antiplatelet therapy (APT) versus plasma exchange (PE) with fresh-frozen plasma (FFP) plus APT

\begin{tabular}{llllll}
\hline Outcome or subgroup title & $\begin{array}{l}\text { No. of } \\
\text { studies }\end{array}$ & $\begin{array}{l}\text { No. of } \\
\text { partici- } \\
\text { pants }\end{array}$ & Statistical method & Effect size \\
\hline 1 Failure of remission <2 weeks & 2 & 140 & Risk Ratio (M-H, Random, 95\% Cl) & $1.48[1.12,1.96]$ \\
\hline $\begin{array}{l}2 \text { Failure to respond (remission) at }>2 \\
\text { weeks to 6 months }\end{array}$ & 2 & 72 & Risk Ratio (M-H, Random, 95\% Cl) & $1.50[0.93,2.42]$ \\
\hline 3 All-cause mortality & 2 & 140 & Risk Ratio (M-H, Random, 95\% Cl) & $1.91[1.09,3.33]$ \\
\hline 4 Relapse rate & 2 & 99 & Risk Ratio (M-H, Random, 95\% Cl) & $0.34[0.10,1.15]$ \\
\hline
\end{tabular}

Analysis 3.1. Comparison 3 TTP studies: Plasma infusions (PI) plus antiplatelet therapy (APT) versus plasma exchange (PE) with fresh-frozen plasma (FFP) plus APT, Outcome 1 Failure of remission $<2$ weeks.

\begin{tabular}{|c|c|c|c|c|c|}
\hline \multirow[t]{2}{*}{ Study or subgroup } & \multirow{2}{*}{$\begin{array}{c}\mathbf{P I}+\mathbf{A P T} \\
\mathbf{n} / \mathbf{N}\end{array}$} & \multirow{2}{*}{$\begin{array}{c}\text { PE with } \\
\text { FFP + APT } \\
\text { n/N }\end{array}$} & Risk Ratio & \multirow[t]{2}{*}{ Weight } & \multirow{2}{*}{$\begin{array}{c}\text { Risk Ratio } \\
\text { M-H, Random, } 95 \% \mathrm{Cl}\end{array}$} \\
\hline & & & M-H, Random, $95 \% \mathrm{Cl}$ & & \\
\hline Henon 1992 & $12 / 19$ & $6 / 19$ & $\longrightarrow$ & $14.29 \%$ & $2[0.95,4.22]$ \\
\hline Rock 1991 & $38 / 51$ & $27 / 51$ & 7 & $85.71 \%$ & $1.41[1.04,1.91]$ \\
\hline Total $(95 \% \mathrm{Cl})$ & 70 & 70 & & $100 \%$ & $1.48[1.12,1.96]$ \\
\hline \multicolumn{6}{|c|}{ Total events: 50 (PI + APT), 33 (PE with FFP + APT) } \\
\hline
\end{tabular}




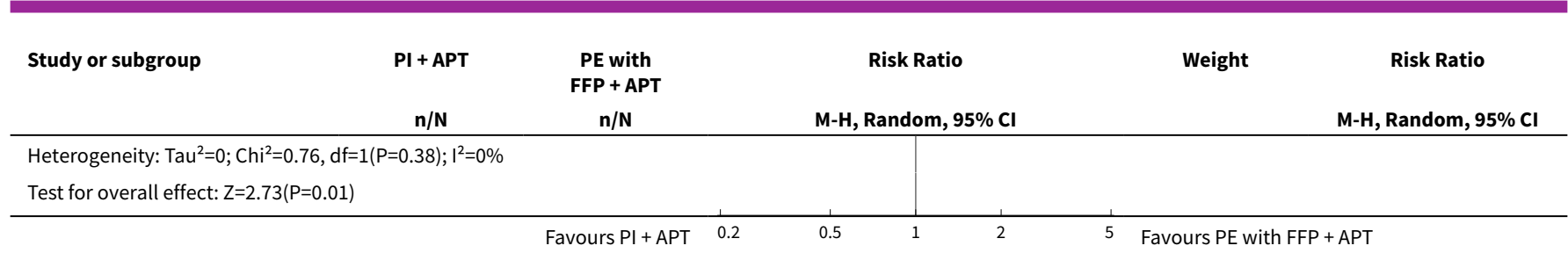

Analysis 3.2. Comparison 3 TTP studies: Plasma infusions (PI) plus antiplatelet therapy (APT) versus plasma exchange (PE) with fresh-frozen plasma (FFP) plus APT, Outcome 2 Failure to respond (remission) at $>2$ weeks to 6 months.

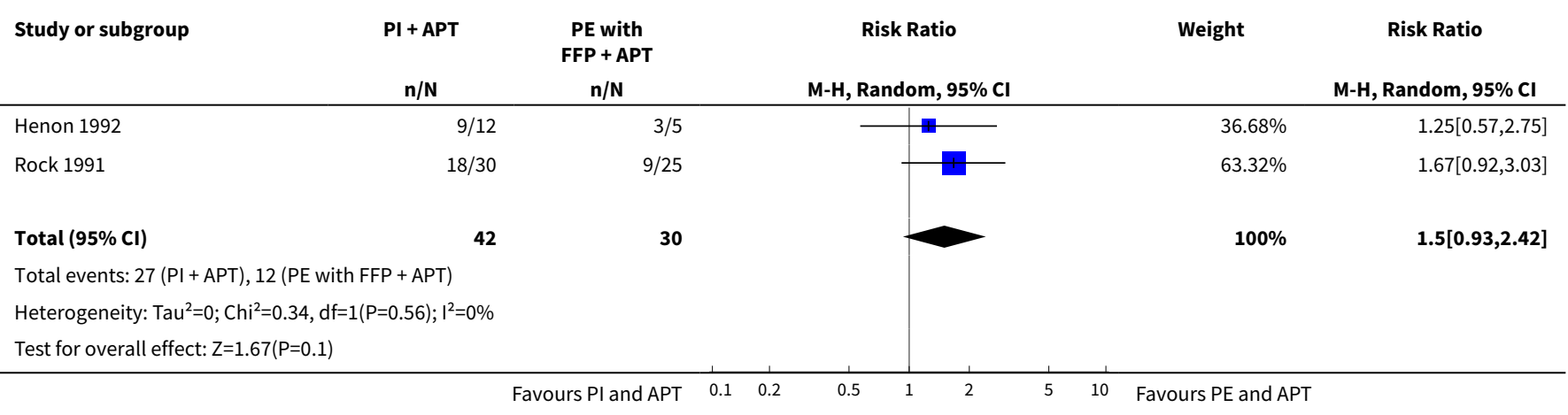

Analysis 3.3. Comparison 3 TTP studies: Plasma infusions (PI) plus antiplatelet therapy (APT) versus plasma exchange (PE) with fresh-frozen plasma (FFP) plus APT, Outcome 3 All-cause mortality.

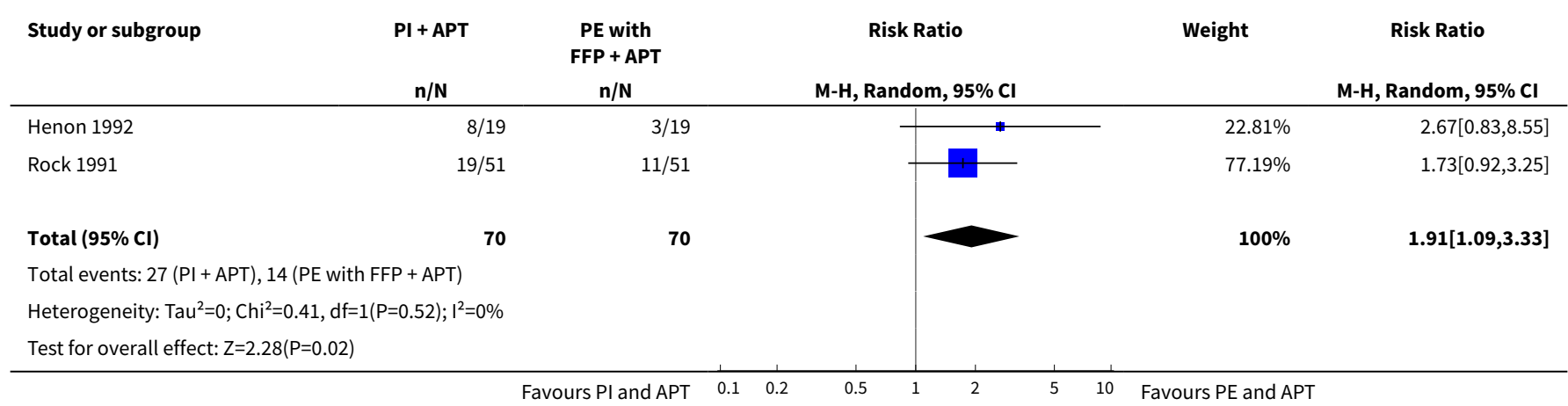

Analysis 3.4. Comparison 3 TTP studies: Plasma infusions (PI) plus antiplatelet therapy (APT) versus plasma exchange (PE) with fresh-frozen plasma (FFP) plus APT, Outcome 4 Relapse rate.

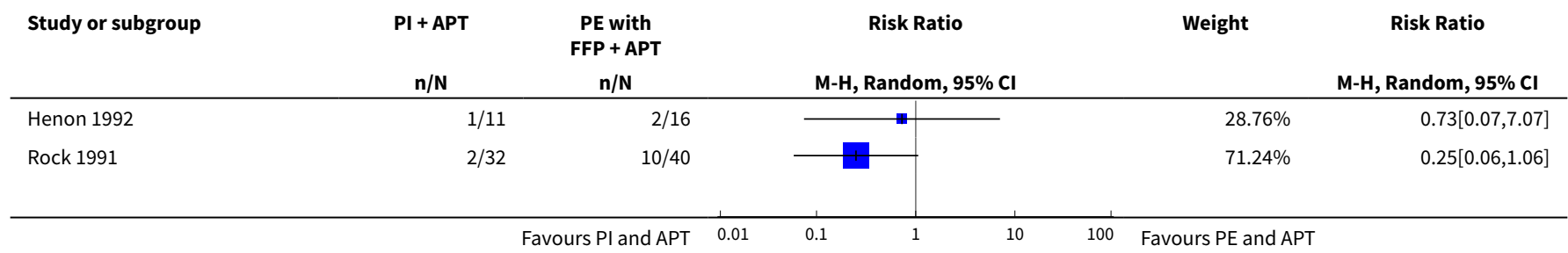




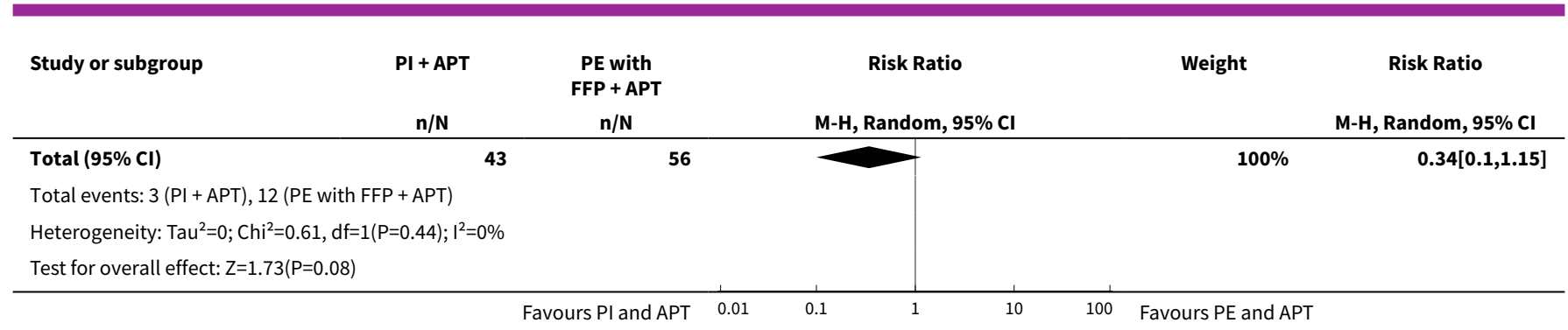

Comparison 4. TTP studies: Antiplatelet therapy (APT) plus plasma exchange (PE) with fresh-frozen plasma (FFP) and steroids versus PE with FFP and steroids

\begin{tabular}{lllll}
\hline Outcome or subgroup title & $\begin{array}{l}\text { No. of } \\
\text { studies }\end{array}$ & $\begin{array}{l}\text { No. of } \\
\text { partici- } \\
\text { pants }\end{array}$ & Statistical method & Effect size \\
\hline 1 Failure of remission at 2 weeks & 1 & & $\begin{array}{l}\text { Risk Ratio (M-H, Random, 95\% } \\
\text { Cl) }\end{array}$ & Totals not selected \\
\hline 2 Failure of remission $>$ 2 weeks & 1 & $\begin{array}{l}\text { Risk Ratio (M-H, Random, 95\% } \\
\text { Cl) }\end{array}$ & Totals not selected \\
\hline 3 All-cause mortality & 1 & $\begin{array}{l}\text { Risk Ratio (M-H, Random, 95\% } \\
\text { Cl) }\end{array}$ & Totals not selected \\
\hline 4 Relapse rate & 1 & $\begin{array}{l}\text { Risk Ratio (M-H, Random, 95\% } \\
\text { Cl) }\end{array}$ & Totals not selected \\
\hline
\end{tabular}

Analysis 4.1. Comparison 4 TTP studies: Antiplatelet therapy (APT) plus plasma exchange (PE) with freshfrozen plasma (FFP) and steroids versus PE with FFP and steroids, Outcome 1 Failure of remission at 2 weeks.

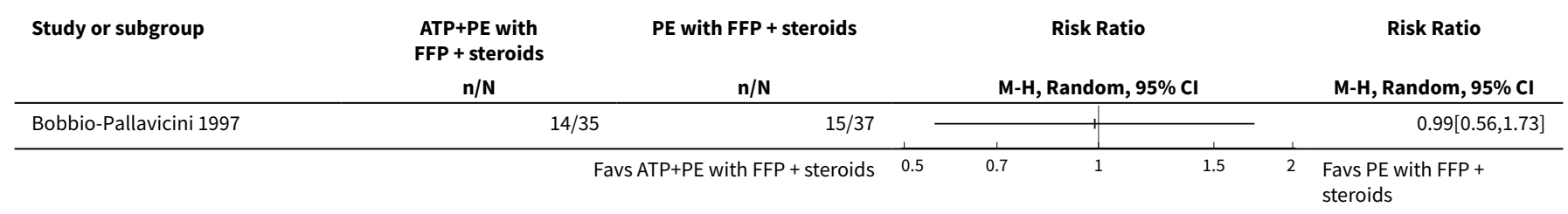

Analysis 4.2. Comparison 4 TTP studies: Antiplatelet therapy (APT) plus plasma exchange (PE) with freshfrozen plasma (FFP) and steroids versus PE with FFP and steroids, Outcome 2 Failure of remission $>2$ weeks.

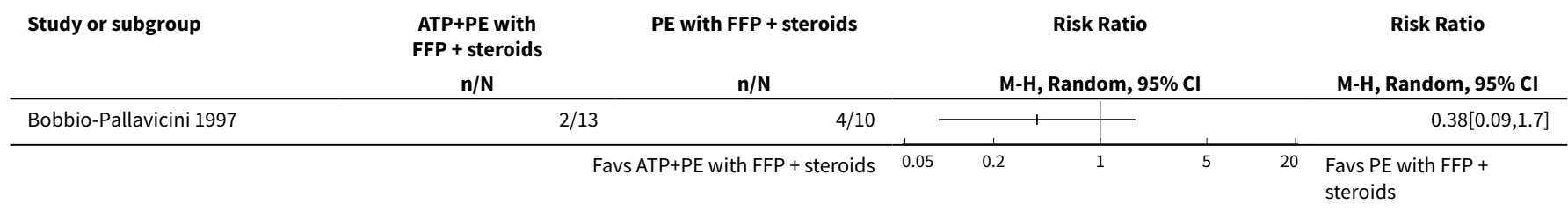


Analysis 4.3. Comparison 4 TTP studies: Antiplatelet therapy (APT) plus plasma exchange (PE) with fresh-frozen plasma (FFP) and steroids versus PE with FFP and steroids, Outcome 3 All-cause mortality.

\begin{tabular}{|c|c|c|c|c|c|c|c|c|c|c|}
\hline \multirow[t]{2}{*}{ Study or subgroup } & $\begin{array}{l}\text { ATP+PE with } \\
\text { FFP + steroids }\end{array}$ & PE with FFP + steroids & \multicolumn{7}{|c|}{ Risk Ratio } & \multirow{2}{*}{$\begin{array}{c}\text { Risk Ratio } \\
\text { M-H, Random, } 95 \% \mathrm{CI}\end{array}$} \\
\hline & $n / N$ & $n / N$ & & & $-H, R$ & dom & $95 \% \mathrm{Cl}$ & & & \\
\hline \multirow[t]{2}{*}{ Bobbio-Pallavicini 1997} & $3 / 35$ & $9 / 37$ & 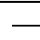 & & & L & & & & $0.35[0.1,1.2]$ \\
\hline & & $\mathrm{ATP}+\mathrm{PE}$ with FFP + steroids & 0.1 & 0.2 & 0.5 & 1 & 2 & 5 & 10 & $\begin{array}{l}\text { Favs PE with FFP + } \\
\text { steroids }\end{array}$ \\
\hline
\end{tabular}

Analysis 4.4. Comparison 4 TTP studies: Antiplatelet therapy (APT) plus plasma exchange (PE) with fresh-frozen plasma (FFP) and steroids versus PE with FFP and steroids, Outcome 4 Relapse rate.

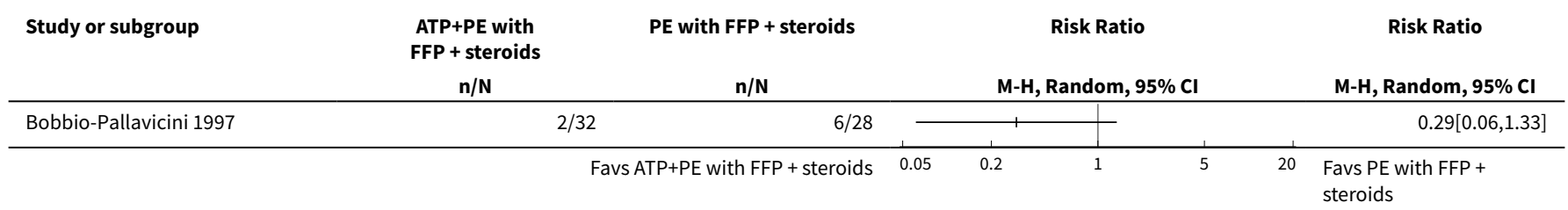

Comparison 5. HUS studies: Any intervention plus supportive therapy versus supportive therapy alone

\begin{tabular}{llllll}
\hline Outcome or subgroup title & $\begin{array}{l}\text { No. of } \\
\text { studies }\end{array}$ & $\begin{array}{l}\text { No. of } \\
\text { partici- } \\
\text { pants }\end{array}$ & Statistical method & Effect size \\
\hline 1 All-cause mortality & 7 & 471 & Risk Ratio (M-H, Random, 95\% Cl) & $1.23[0.59,2.57]$ \\
\hline 2 Neurological and extra renal events & 3 & 297 & Risk Ratio (M-H, Random, 95\% Cl) & $0.80[0.48,1.32]$ \\
\hline 3 Proteinuria at last follow-up & 3 & 207 & Risk Ratio (M-H, Random, 95\% Cl) & $1.34[0.23,7.79]$ \\
\hline 4 Hypertension at last follow-up & 4 & 204 & Risk Ratio (M-H, Random, 95\% Cl) & $0.85[0.24,3.07]$ \\
\hline
\end{tabular}

Analysis 5.1. Comparison 5 HUS studies: Any intervention plus supportive therapy versus supportive therapy alone, Outcome 1 All-cause mortality.

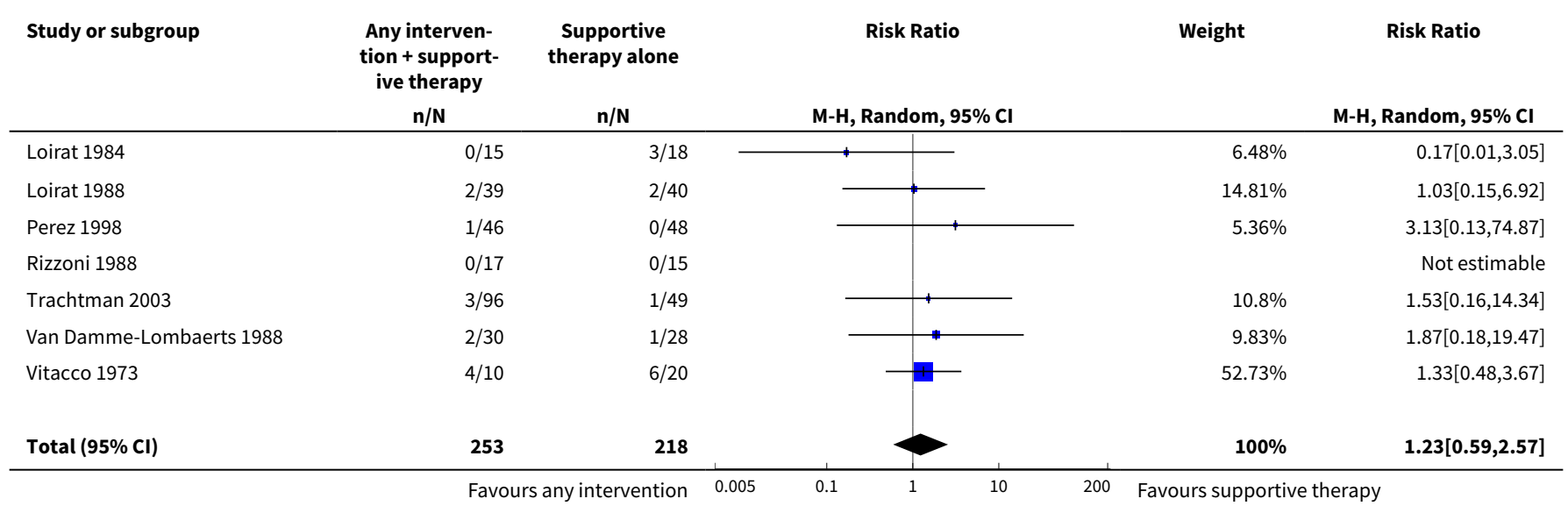




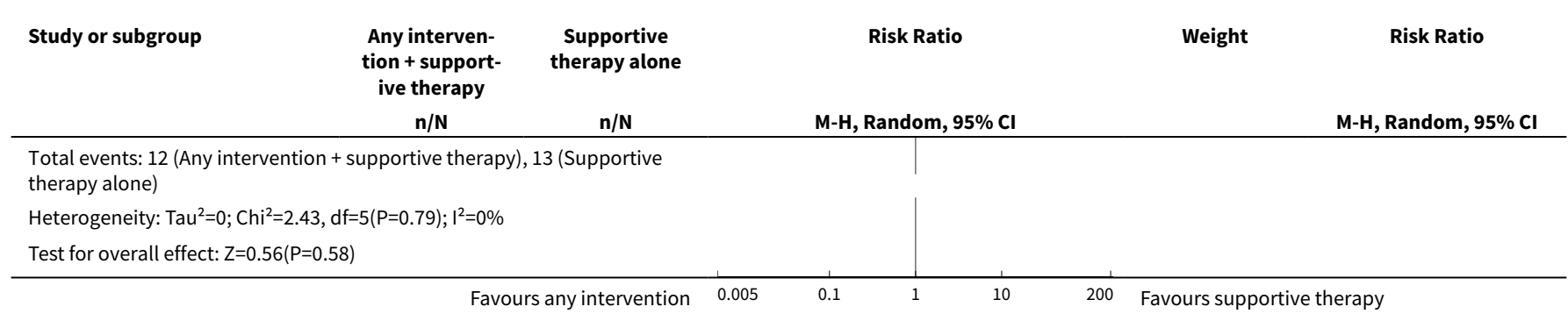

Analysis 5.2. Comparison 5 HUS studies: Any intervention plus supportive therapy versus supportive therapy alone, Outcome 2 Neurological and extra renal events.

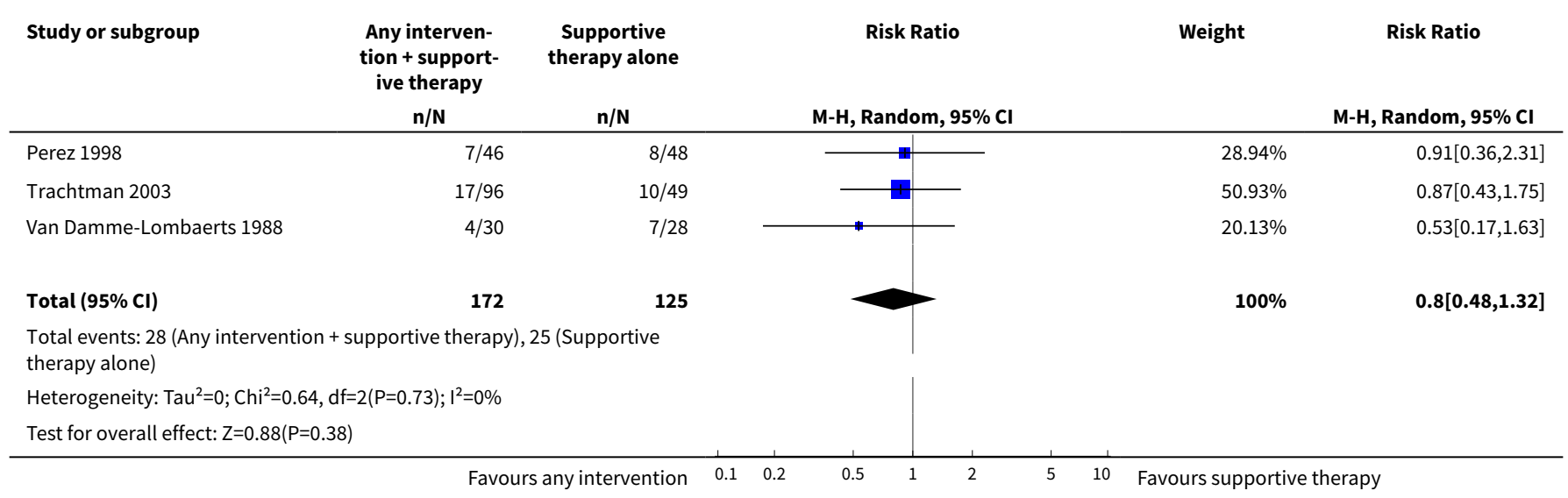

Analysis 5.3. Comparison 5 HUS studies: Any intervention plus supportive therapy versus supportive therapy alone, Outcome 3 Proteinuria at last follow-up.

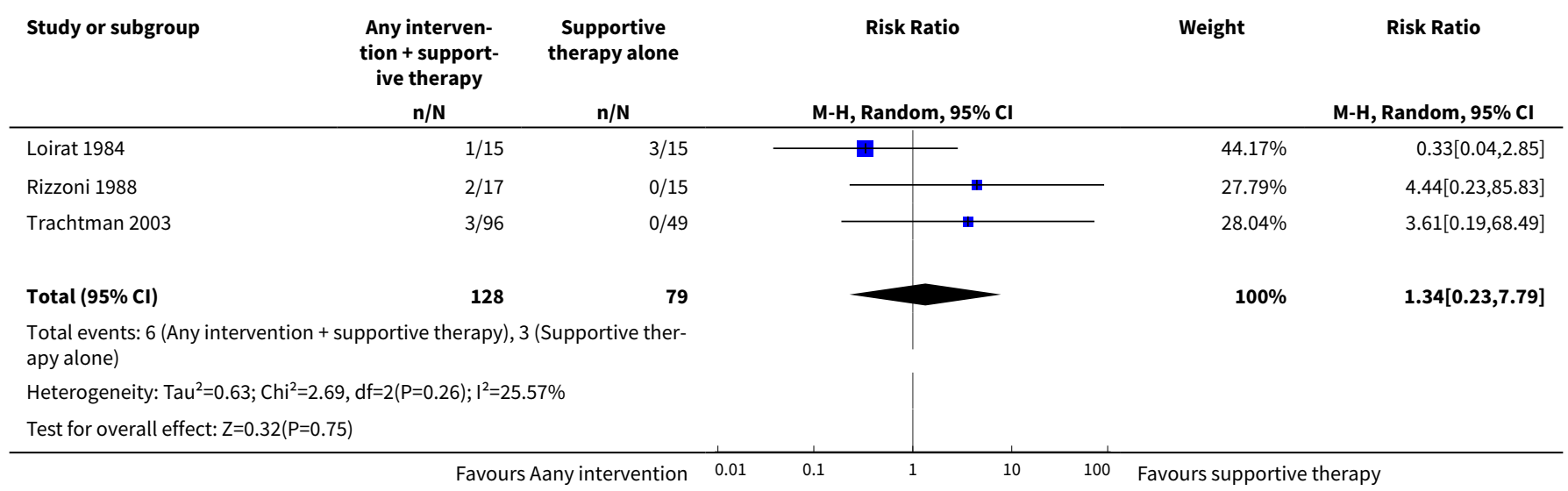


Analysis 5.4. Comparison 5 HUS studies: Any intervention plus supportive therapy versus supportive therapy alone, Outcome 4 Hypertension at last follow-up.

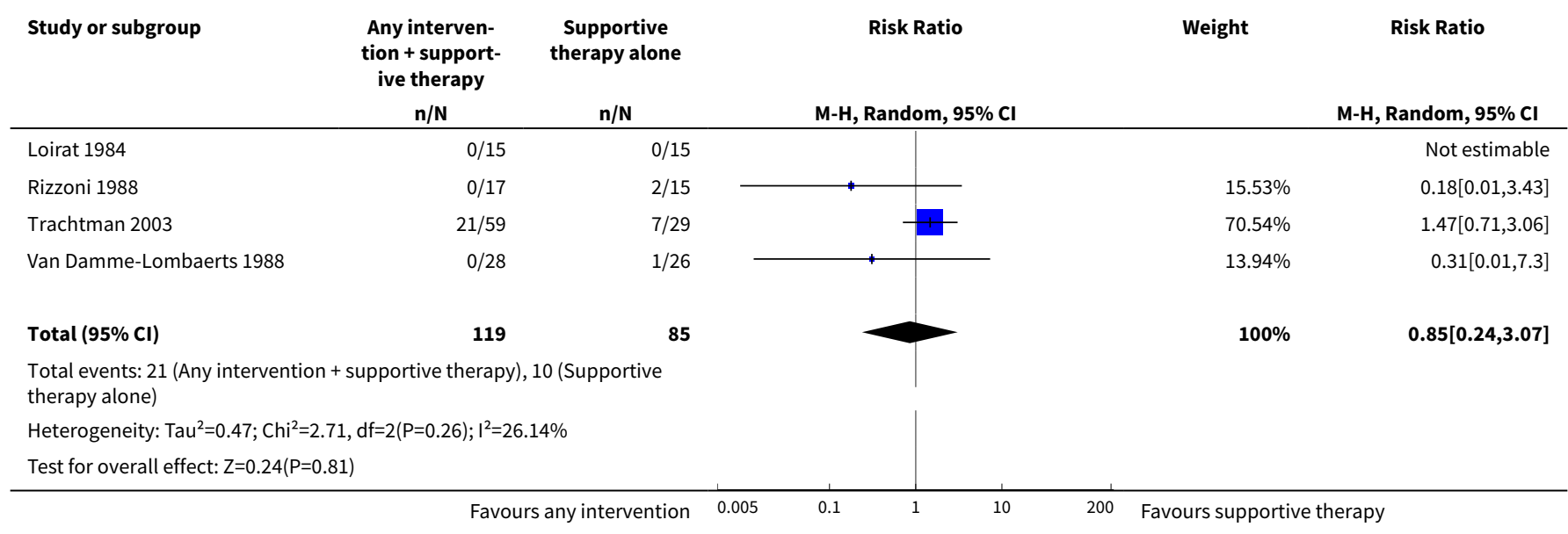

\section{Comparison 6. HUS studies: Anticoagulation (heparin +/- dipyridamole or urokinase) plus supportive therapy versus supportive therapy alone}

\begin{tabular}{|c|c|c|c|c|}
\hline Outcome or subgroup title & $\begin{array}{l}\text { No. of } \\
\text { studies }\end{array}$ & $\begin{array}{l}\text { No. of } \\
\text { partici- } \\
\text { pants }\end{array}$ & Statistical method & Effect size \\
\hline 1 All-cause mortality & 3 & 121 & Risk Ratio (M-H, Random, 95\% Cl) & $1.13[0.43,2.95]$ \\
\hline $\begin{array}{l}2 \text { Neurological events: Children } \\
\text { with seizures }\end{array}$ & 1 & & Risk Ratio (M-H, Random, 95\% Cl) & Totals not selected \\
\hline 3 Renal biopsy: cortical necrosis & 0 & & Risk Ratio (M-H, Random, 95\% Cl) & Totals not selected \\
\hline $\begin{array}{l}4 \text { Renal biopsy: Thrombotic mi- } \\
\text { croangiopathy }\end{array}$ & 1 & & Risk Ratio (M-H, Random, 95\% Cl) & Totals not selected \\
\hline $\begin{array}{l}5 \text { Proteinuria }>0.10 \mathrm{~g} / 24 \mathrm{~h} \text { at last } \\
\text { follow-up }\end{array}$ & 1 & & Risk Ratio (M-H, Random, 95\% Cl) & Totals not selected \\
\hline 6 Hypertension at last follow-up & 2 & & Risk Ratio (M-H, Random, 95\% Cl) & Totals not selected \\
\hline $\begin{array}{l}7 \mathrm{GFR}<80 \mathrm{~mL} / \mathrm{min} / 1.73 \mathrm{~m}^{2} \text { at last } \\
\text { follow-up }\end{array}$ & 0 & & Risk Ratio (M-H, Random, 95\% Cl) & Totals not selected \\
\hline 8 Adverse effect: Bleeding (RR) & 3 & 124 & Risk Ratio (M-H, Random, 95\% Cl) & $25.89[3.67,182.83]$ \\
\hline $\begin{array}{l}9 \text { Adverse effect: Bleeding (RD } \\
\text { random effects model) }\end{array}$ & 3 & 124 & Risk Difference (M-H, Random, 95\% Cl) & $0.44[-0.39,1.28]$ \\
\hline $\begin{array}{l}10 \text { Adverse effect: Bleeding (RD } \\
\text { fixed effect model) }\end{array}$ & 3 & 124 & Risk Difference (M-H, Fixed, 95\% Cl) & $0.35[0.25,0.45]$ \\
\hline
\end{tabular}


Analysis 6.1. Comparison 6 HUS studies: Anticoagulation (heparin +/- dipyridamole or urokinase) plus supportive therapy versus supportive therapy alone, Outcome 1 All-cause mortality.

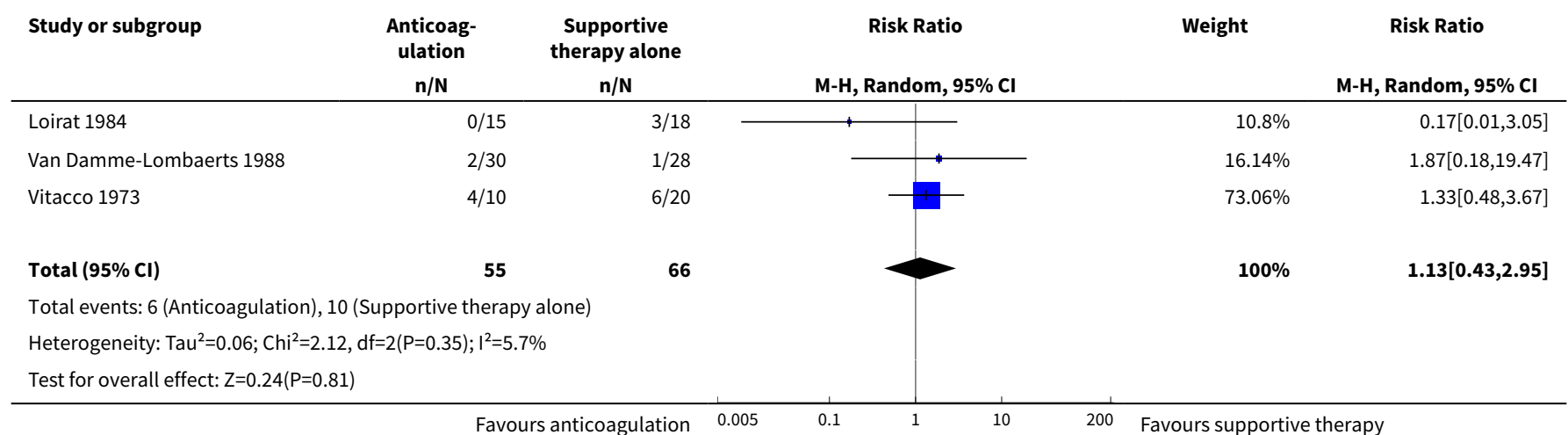

Analysis 6.2. Comparison 6 HUS studies: Anticoagulation (heparin + -- dipyridamole or urokinase) plus supportive therapy versus supportive therapy alone, Outcome 2 Neurological events: Children with seizures.

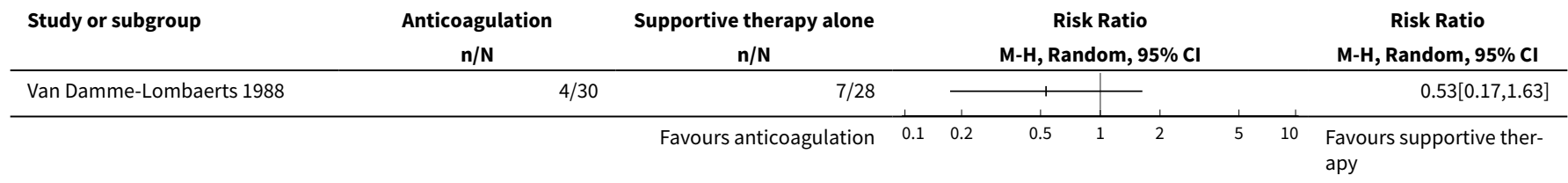

Analysis 6.4. Comparison 6 HUS studies: Anticoagulation (heparin +/- dipyridamole or urokinase) plus supportive therapy versus supportive therapy alone, Outcome 4 Renal biopsy: Thrombotic microangiopathy.

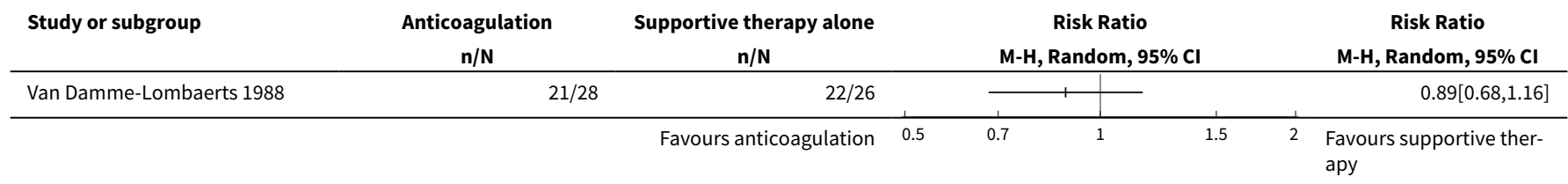

Analysis 6.5. Comparison 6 HUS studies: Anticoagulation (heparin +/- dipyridamole or urokinase) plus supportive therapy versus supportive therapy alone, Outcome 5 Proteinuria $>0.10 \mathrm{~g} / 24 \mathrm{~h}$ at last follow-up.

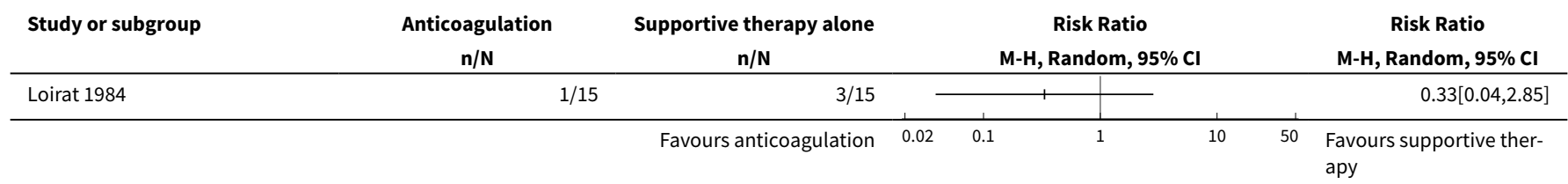


Analysis 6.6. Comparison 6 HUS studies: Anticoagulation (heparin +/- dipyridamole or urokinase) plus supportive therapy versus supportive therapy alone, Outcome 6 Hypertension at last follow-up.

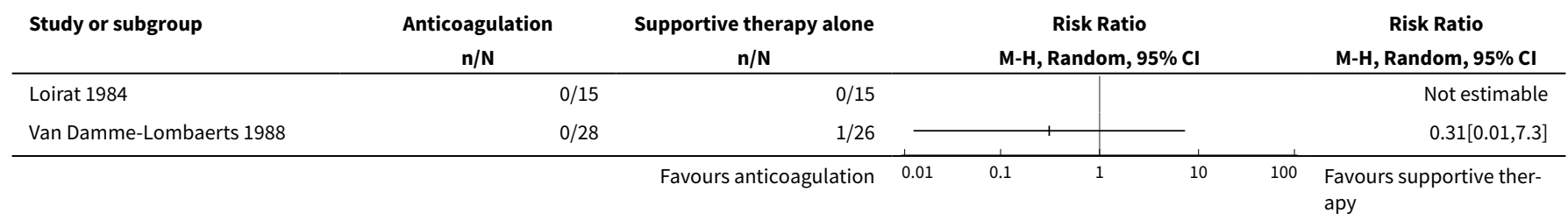

Analysis 6.8. Comparison 6 HUS studies: Anticoagulation (heparin +/- dipyridamole or urokinase) plus supportive therapy versus supportive therapy alone, Outcome 8 Adverse effect: Bleeding (RR).

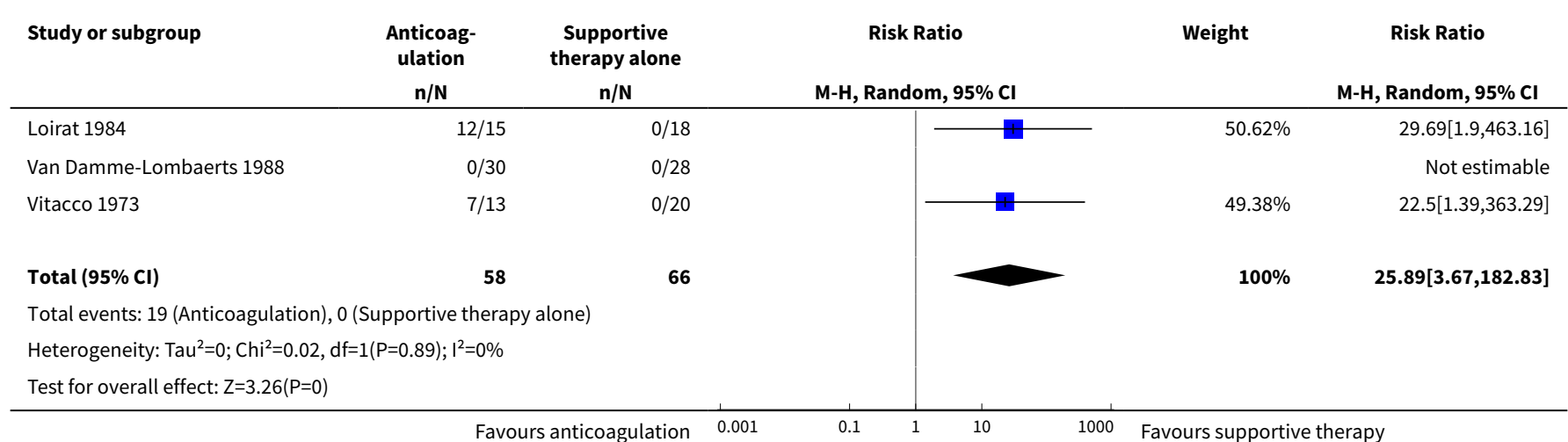

Analysis 6.9. Comparison 6 HUS studies: Anticoagulation (heparin +/- dipyridamole or urokinase) plus supportive therapy versus supportive therapy alone, Outcome 9 Adverse effect: Bleeding (RD random effects model).

\begin{tabular}{|c|c|c|c|c|c|}
\hline Study or subgroup & $\begin{array}{l}\text { Anticoag- } \\
\text { ulation } \\
n / N\end{array}$ & $\begin{array}{c}\text { Supportive } \\
\text { therapy alone } \\
n / N\end{array}$ & $\begin{array}{c}\text { Risk Difference } \\
\text { M-H, Random, 95\% CI }\end{array}$ & Weight & $\begin{array}{c}\text { Risk Difference } \\
\text { M-H, Random, 95\% Cl }\end{array}$ \\
\hline Loirat 1984 & $12 / 15$ & $0 / 18$ & $\rightarrow-$ & $33.24 \%$ & $0.8[0.59,1.01]$ \\
\hline Van Damme-Lombaerts 1988 & $0 / 30$ & $0 / 28$ & $\#$ & $33.93 \%$ & $0[-0.06,0.06]$ \\
\hline Vitacco 1973 & $7 / 13$ & $0 / 20$ & $\longrightarrow$ & $32.83 \%$ & $0.54[0.27,0.81]$ \\
\hline Total $(95 \% \mathrm{Cl})$ & 58 & 66 & & $100 \%$ & $0.44[-0.39,1.28]$ \\
\hline \multicolumn{6}{|c|}{ Total events: 19 (Anticoagulation), 0 (Supportive therapy alone) } \\
\hline \multicolumn{6}{|c|}{ Heterogeneity: $\mathrm{Tau}^{2}=0.53 ; \mathrm{Chi}^{2}=132.22, \mathrm{df}=2(\mathrm{P}<0.0001) ; \mathrm{I}^{2}=98.49 \%$} \\
\hline Test for overall effect: $Z=1.04($ & & & & & \\
\hline
\end{tabular}


Analysis 6.10. Comparison 6 HUS studies: Anticoagulation (heparin +/- dipyridamole or urokinase) plus supportive therapy versus supportive therapy alone, Outcome 10 Adverse effect: Bleeding (RD fixed effect model).

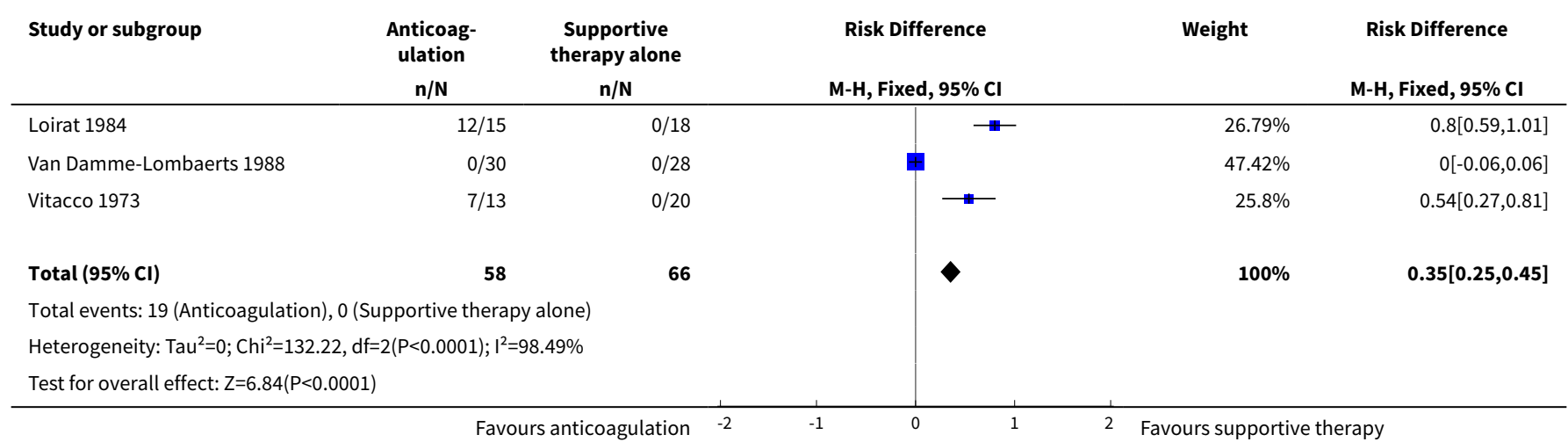

Comparison 7. HUS studies: Plasma infusion plus supportive therapy versus supportive therapy alone

\begin{tabular}{llllll}
\hline Outcome or subgroup title & $\begin{array}{l}\text { No. of } \\
\text { studies }\end{array}$ & $\begin{array}{l}\text { No. of } \\
\text { partici- } \\
\text { pants }\end{array}$ & Statistical method & Effect size \\
\hline 1 All-cause mortality & 2 & 111 & Risk Ratio (M-H, Random, 95\% Cl) & $1.03[0.15,6.92]$ \\
\hline $\begin{array}{l}\text { 2 ESKD: Dialysis-dependent at 6 } \\
\text { weeks }\end{array}$ & 2 & 111 & Risk Ratio (M-H, Random, 95\% Cl) & $1.03[0.15,6.92]$ \\
\hline $\begin{array}{l}\text { 3 Proteinuria at last follow-up (12 } \\
\text { months) }\end{array}$ & 2 & 92 & Risk Ratio (M-H, Random, 95\% Cl) & $0.96[0.13,7.14]$ \\
\hline $\begin{array}{l}\text { 4 Hypertension at last follow-up (12 } \\
\text { months) }\end{array}$ & 2 & 92 & Risk Ratio (M-H, Random, 95\% Cl) & $0.68[0.16,2.86]$ \\
\hline
\end{tabular}

Analysis 7.1. Comparison 7 HUS studies: Plasma infusion plus supportive therapy versus supportive therapy alone, Outcome 1 All-cause mortality.

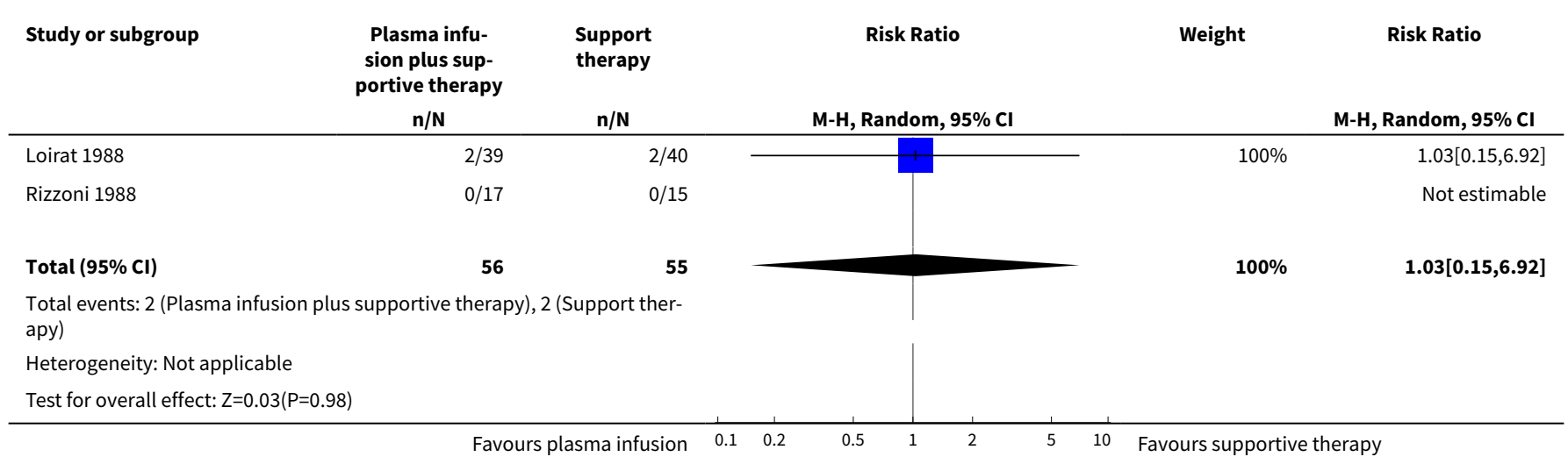


Analysis 7.2. Comparison 7 HUS studies: Plasma infusion plus supportive therapy versus supportive therapy alone, Outcome 2 ESKD: Dialysis-dependent at 6 weeks.

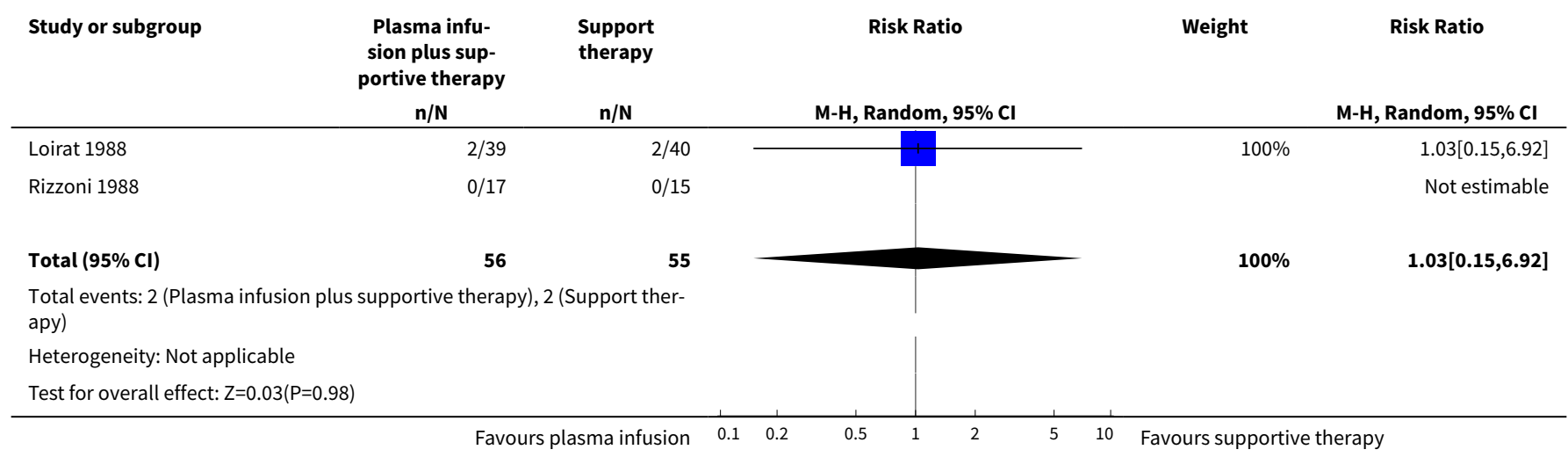

Analysis 7.3. Comparison 7 HUS studies: Plasma infusion plus supportive therapy versus supportive therapy alone, Outcome 3 Proteinuria at last follow-up (12 months).

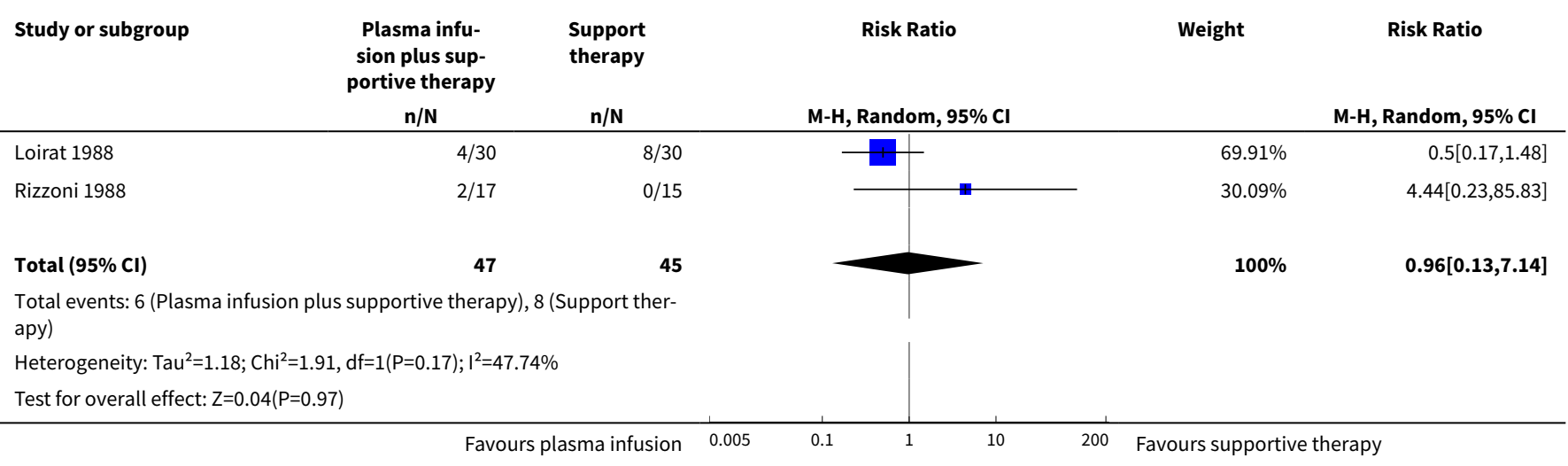

Analysis 7.4. Comparison 7 HUS studies: Plasma infusion plus supportive therapy versus supportive therapy alone, Outcome 4 Hypertension at last follow-up (12 months).

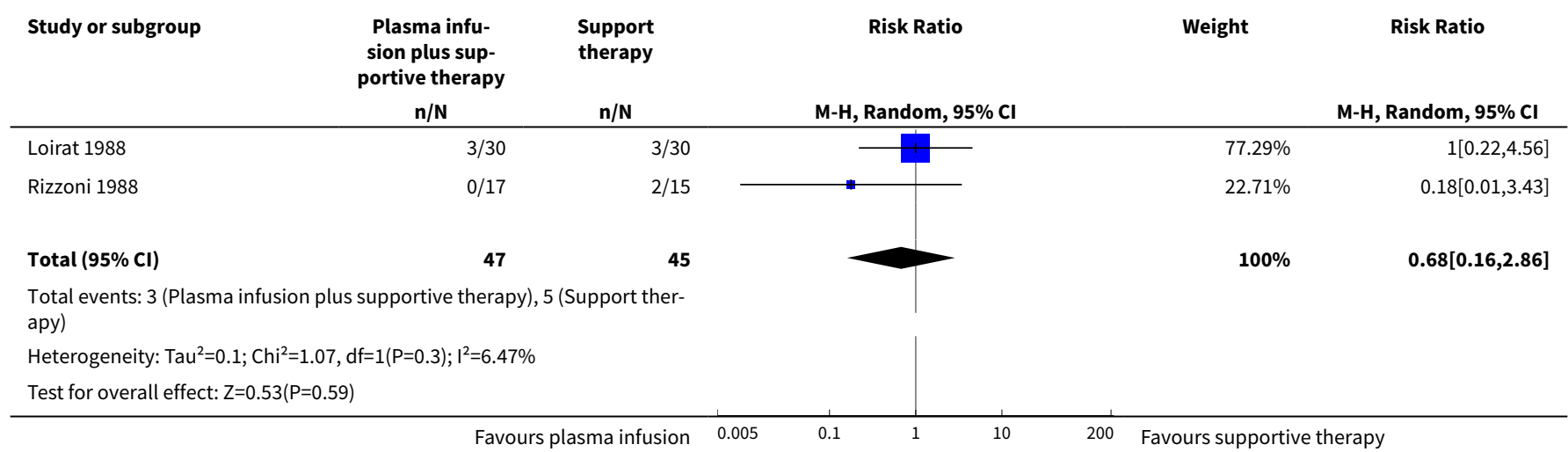


Comparison 8. HUS studies: Methylprednisolone plus supportive therapy versus placebo plus supportive therapy

\begin{tabular}{lllll}
\hline Outcome or subgroup title & $\begin{array}{l}\text { No. of } \\
\text { studies }\end{array}$ & $\begin{array}{l}\text { No. of } \\
\text { partici- } \\
\text { pants }\end{array}$ & Statistical method & Effect size \\
\hline 1 All-cause mortality & 1 & Risk Ratio (M-H, Random, 95\% Cl) & Totals not selected \\
\hline $\begin{array}{l}\text { 2 Neurological events: Children } \\
\text { with seizures }\end{array}$ & 1 & Risk Ratio (M-H, Random, 95\% Cl) & Totals not selected \\
\hline 3 Adverse effects: Peritonitis & 1 & Risk Ratio (M-H, Random, 95\% Cl) & Totals not selected \\
\hline
\end{tabular}

Analysis 8.1. Comparison 8 HUS studies: Methylprednisolone plus supportive therapy versus placebo plus supportive therapy, Outcome 1 All-cause mortality.

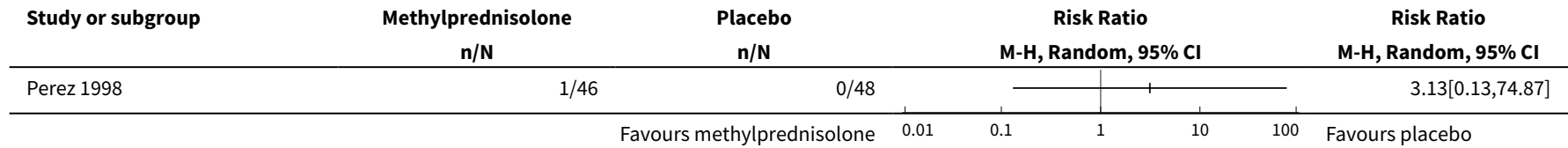

Analysis 8.2. Comparison 8 HUS studies: Methylprednisolone plus supportive therapy versus placebo plus supportive therapy, Outcome 2 Neurological events: Children with seizures.

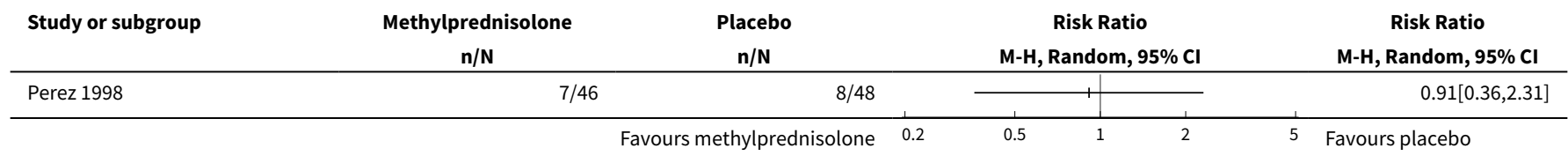

Analysis 8.3. Comparison 8 HUS studies: Methylprednisolone plus supportive therapy versus placebo plus supportive therapy, Outcome 3 Adverse effects: Peritonitis.

\begin{tabular}{|c|c|c|c|c|c|c|}
\hline Study or subgroup & $\begin{array}{c}\text { Methylprednisolone } \\
\mathbf{n} / \mathbf{N}\end{array}$ & $\begin{array}{c}\text { Placebo } \\
n / N\end{array}$ & & \multicolumn{2}{|c|}{$\begin{array}{c}\text { Risk Ratio } \\
\text { M-H, Random, } 95 \% \mathrm{Cl}\end{array}$} & \multirow{2}{*}{$\begin{array}{c}\text { Risk Ratio } \\
\text { M-H, Random, 95\% Cl } \\
1.48[0.8,2.74\end{array}$} \\
\hline Perez 1998 & $17 / 46$ & $12 / 48$ & & & \begin{tabular}{l|l} 
&, 1
\end{tabular} & \\
\hline
\end{tabular}

Comparison 9. HUS studies: Shiga toxin binding agent plus supportive therapy versus placebo plus supportive care

\begin{tabular}{lllll}
\hline Outcome or subgroup title & $\begin{array}{l}\text { No. of } \\
\text { studies }\end{array}$ & $\begin{array}{l}\text { No. of } \\
\text { partici- } \\
\text { pants }\end{array}$ & Statistical method & Effect size \\
\hline 1 All-cause mortality & 1 & Risk Ratio $(\mathrm{M}-\mathrm{H}$, Random, $95 \% \mathrm{Cl})$ & Totals not selected \\
\hline 2 Extrarenal events & 1 & Risk Ratio $(\mathrm{M}-\mathrm{H}$, Random, $95 \% \mathrm{Cl})$ & Totals not selected \\
\hline
\end{tabular}




\begin{tabular}{lllll}
\hline Outcome or subgroup title & $\begin{array}{l}\text { No. of } \\
\text { studies }\end{array}$ & $\begin{array}{l}\text { No. of } \\
\text { partici- } \\
\text { pants }\end{array}$ & Statistical method & Effect size \\
\hline $\begin{array}{l}3 \text { Proteinuria } \geq 2 \text { at last fol- } \\
\text { low-up ( } 60 \text { days) }\end{array}$ & 1 & Risk Ratio $(\mathrm{M}-\mathrm{H}$, Random, $95 \% \mathrm{Cl})$ & Totals not selected \\
\hline $\begin{array}{l}4 \text { Hypertension at last follow-up } \\
(60 \text { days })\end{array}$ & 1 & Risk Ratio $(\mathrm{M}-\mathrm{H}$, Random, $95 \% \mathrm{Cl})$ & Totals not selected \\
\hline $\begin{array}{l}5 \mathrm{GFR}<90 \mathrm{~mL} / \mathrm{min} / 1.73 \mathrm{~m}^{2} \text { at } \\
\text { last follow-up }(60 \text { days })\end{array}$ & 1 & Risk Ratio $(\mathrm{M}-\mathrm{H}$, Random, $95 \% \mathrm{Cl})$ & Totals not selected \\
\hline
\end{tabular}

Analysis 9.1. Comparison 9 HUS studies: Shiga toxin binding agent plus supportive therapy versus placebo plus supportive care, Outcome 1 All-cause mortality.

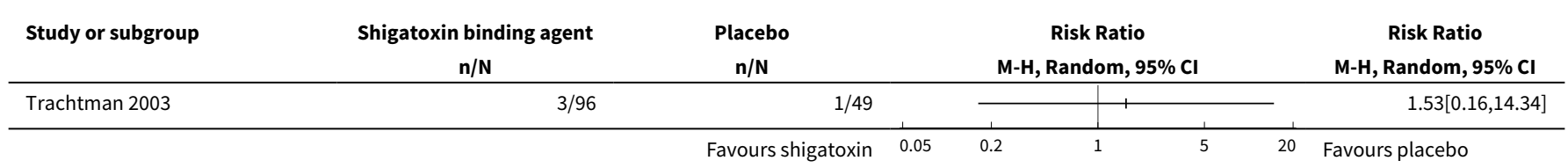

Analysis 9.2. Comparison 9 HUS studies: Shiga toxin binding agent plus supportive therapy versus placebo plus supportive care, Outcome 2 Extrarenal events.

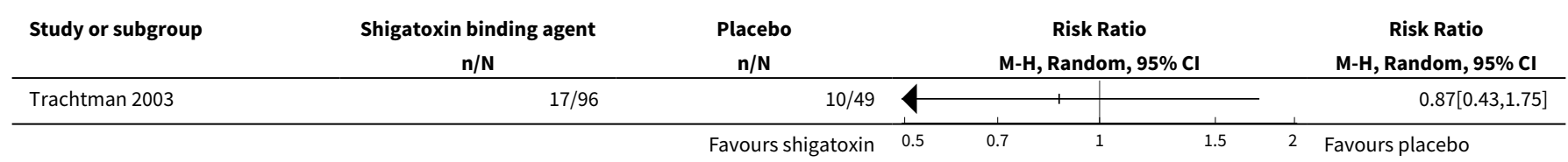

Analysis 9.3. Comparison 9 HUS studies: Shiga toxin binding agent plus supportive therapy versus placebo plus supportive care, Outcome 3 Proteinuria $\geq 2$ at last follow-up (60 days).

\begin{tabular}{|c|c|c|c|c|c|c|c|}
\hline \multirow{2}{*}{$\begin{array}{l}\text { Study or subgroup } \\
\text { Trachtman } 2003\end{array}$} & $\begin{array}{l}\text { Shigatoxin binding agent } \\
n / N\end{array}$ & $\begin{array}{c}\text { Placebo } \\
\mathrm{n} / \mathrm{N}\end{array}$ & \multicolumn{3}{|c|}{$\begin{array}{c}\text { Risk Ratio } \\
\text { M-H, Random, } 95 \% \mathrm{Cl} \\
\end{array}$} & & \multirow{2}{*}{$\begin{array}{c}\text { Risk Ratio } \\
\text { M-H, Random, 95\% Cl } \\
3.61[0.19,68.49\end{array}$} \\
\hline & $3 / 96$ & $0 / 49$ & & & 1 & & \\
\hline
\end{tabular}

Analysis 9.4. Comparison 9 HUS studies: Shiga toxin binding agent plus supportive therapy versus placebo plus supportive care, Outcome 4 Hypertension at last follow-up (60 days).

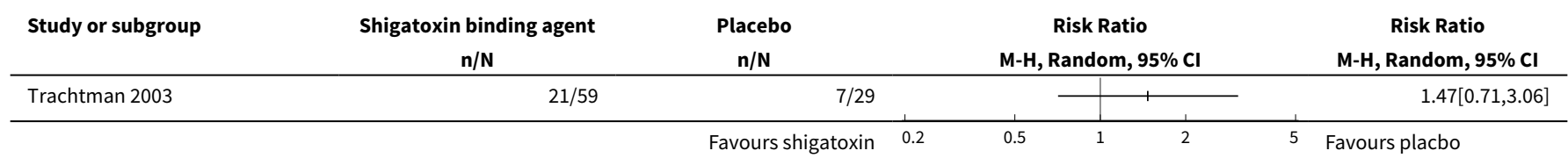




\section{Analysis 9.5. Comparison 9 HUS studies: Shiga toxin binding agent plus supportive therapy versus placebo plus supportive care, Outcome $5 \mathrm{GFR}<90 \mathrm{~mL} / \mathrm{min} / 1.73 \mathrm{~m}^{2}$ at last follow-up (60 days).}

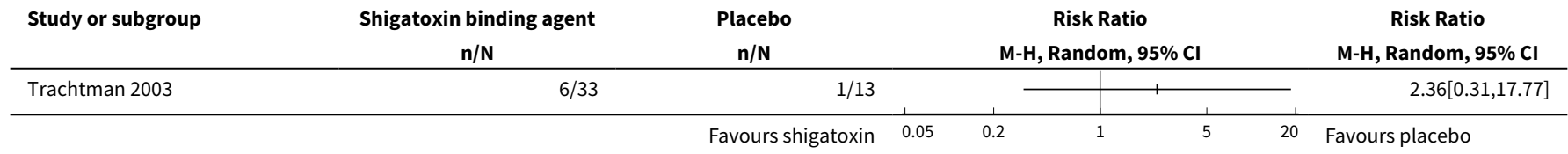

\section{APPEN DICES}

Appendix 1. Electronic search strategies

\begin{tabular}{ll}
\hline Database & Search terms \\
\hline CENTRAL & 1. haemolytic uraemic syndrome \\
& 2. hemolytic uremic syndrome \\
& 3. thrombotic thrombocytopaenic purpura \\
4. thrombotic thrombocytopenic purpura & 5. \#1 or \#2 or \#3 or \#4 \\
\hline MEDLINE & 1. hemolytic uremic syndrome/ \\
& 2. hemolytic ur?emic syndrome.tw \\
& 3. haemolytic ur?emic syndrome.tw \\
& 4. purpura thrombotic thrombocytopenic/ \\
& 5. thrombotic thrombocytop?enic purpura.tw. \\
6. or/1-5 \\
\hline EMBASE & 1. hemolytic uremic syndrome/ \\
2. haemolytic ur?emic syndrome.tw. \\
3. hemolytic ur?emic syndrome.tw \\
4. thrombotic thrombocytopenic purpura/ \\
5. thrombotic thrombocytop?enic purpura.tw. \\
6. or/1-5
\end{tabular}

WHAT'S NEW

\begin{tabular}{lll}
\hline Date & Event & Description \\
\hline 23 September 2008 & Amended & Converted to new review format. \\
\hline
\end{tabular}

\section{CONTRIBUTIONS OFAUTHORS}

- Mini Michael: Designed the review; screened search results; screened retrieved papers; appraised quality of papers; abstracted data; wrote to authors for additional information; obtained and screened data on unpublished studies; data entry into RevMan; analysed data; provided a clinical perspective and wrote review. 
- Elizabeth Elliott: Conceived the idea and designed the review; screened search results; screened retrieved papers; appraised quality of papers; abstracted data; wrote to authors for additional information; obtained and screened data on unpublished studies; data entry into RevMan; analysed data; provided a clinical perspective and wrote the review.

- Greta Ridley: Screened searched results; screened retrieved papers; appraised quality of papers; abstracted data; obtained and screened data on unpublished studies; data entry into RevMan; analysed data.

- Elisabeth Hodson: Methodological input.

- Jonathan Craig: Methodological input; quality appraisal; data analysis; clinical perspective and writing of review.

\section{DECLARATIONSOF INTEREST}

None declared

\section{SOURCES OF SUPPORT}

\section{Internal sources}

- No sources of support supplied

\section{External sources}

- Centre for Clinical Research Excellence in Renal Medicine Scholarship, Australia.

- National Health and Medical Research Council of Australia Practitioner Fellowship (No. 457084), Australia.

\section{N DEX TERMS}

\section{Medical Subject Headings (MeSH)}

Cyclophosphamide [therapeutic use]; Hemolytic-Uremic Syndrome [*therapy]; Immunoglobulins, Intravenous [therapeutic use]; Immunosuppressive Agents [ ${ }^{\star}$ therapeutic use]; Mycophenolic Acid [analogs \& derivatives] [therapeutic use]; Plasma Exchange; Purpura, Thrombotic Thrombocytopenic [*therapy]; Randomized Controlled Trials as Topic

\section{MeSH check words}

Humans 